\title{
Citizens of Empire: Puerto Rico, Status, and Constitutional Change
}

\author{
Sam Erman*
}

This Article proposes a new account of how empire became constitutional. When the United States took a deliberate imperial turn in 1898-1899 by annexing Puerto Rico and the Philippines, many jurists thought that the Constitution automatically made these islands proto-states and their residents U.S. citizens with full constitutional protections. Three decades later, this expansive view was no longer mainstream. Contrary to standard accounts, this momentous change was neither quick nor the result of unilateral judicial action. To perceive dynamics extending beyond the judiciary, this study examines the attempts to win U.S. citizenship for Puerto Ricans by their first representative in Washington, Federico Degetau $y$ González. Aware that constitutional meaning was not exclusively the province of courts, Degetau brought claims to U.S. citizenship before administrators, legislators, and the President as well. Officials

Copyright (C) 2014 California Law Review, Inc. California Law Review, Inc. (CLR) is a California nonprofit corporation. CLR and the authors are solely responsible for the content of their publications.

* Assistant Professor, USC Gould School of Law. In addition to those acknowledged in his dissertation, the author thanks Nicholas Bagley, Rabia Belt, Mary Sarah Bilder, the Honorable José Cabranes, Kristin Collins, Akiba Covitz, Kristina Daugirdas, Christine Desan, Holger Droessler, Linda Elliott, Dan Ernst, Richard Friedman, Sarah Barringer Gordon, Annette Gordon-Reed, Tom Green, Don Herzog, Jay Hook, Morton Horwitz, Michael Klarman, Jedidiah Kroncke, Adriaan Lanni, Julianna Lee, Sophia Lee, Kenneth Mack, Bruce Mann, Maeva Marcus, Serena Mayeri, Martha Minow, Gerald Neuman, William Novak, James Oldham, J.J. Prescott, Richard Primus, Gautham Rao, Emma Rothschild, Rebecca Scott, Jed Shugerman, Sonia Starr, Karen Tani, Mark Tushnet, his co-clerks and co-fellows, and the Berger and Latino Studies Fellowship Programs. He also thanks Jessica Kenny, Andrew Talai, Rory Collins, Lauren Blakely, and Margaret Dreschel of the California Law Review; the staffs of the Library of Congress, the Supreme Court Library, and the Harvard Law School Library; the law faculties at the Universities of Chicago, Michigan, San Diego, and Southern California; and entry-level legal-academic committees at American University Washington College of Law, George Washington University Law School, Georgetown University Law Center, Harvard Law School, Maurice A. Deane School of Law at Hofstra University, Loyola University Chicago School of Law, New York University School of Law, Peking University School of Transnational Law, UCLA School of Law, University of Georgia School of Law, University of Illinois College of Law, University of Pennsylvania Law School, University of Texas School of Law, University of Virginia School of Law, and the University of Washington School of Law. Archival abbreviations appear in the Appendix. 
responded with evasions through concessions. When Degetau sought a right as a citizen, they granted it on other grounds. Meanings of U.S. citizenship changed as officials reduced the rights that would accompany a grant of citizenship while envisioning without endorsing the possibility of noncitizen U.S. nationals. That novel idea-like the ideas of U.S. lands that would never be states and U.S. people with less than full constitutional rights-ripened into conventional wisdom and, eventually, similar doctrine that remains binding today. This suggests that the constitutional law of empire emerged as judges together with administrative and elected officials engaged in an iterative process in which they deployed forms of creative ambiguity to manage perceived conflicts between the Constitution and empire.

Introduction 1182

I. U.S. Rule in the Shadow of the Constitution, 1898-1900 1189

II. Ambiguous Declarations: The Insular Cases of 1901 1200

III. Degetau Seeks Citizenship Without Filing Suit, 1901-1902. 1204

IV. Degetau Turns to Test Cases for Citizenship, 1902-1905 1213

V. Post-Degetau Politics and Constitutional Settlement

Appendix: List of Abbreviations

\section{INTRODUCTION}

Resident Commissioner Federico Degetau y González had a constitutional problem. As the first elected representative of Puerto Rico in Washington following U.S. invasion and annexation of the island in 1898-1899, he sought for his countrymen legal recognition as U.S. citizens. The status, he presumed, would bring with it full constitutional protections for islanders and classification of Puerto Rico as a traditional territory soon to be a state. Believing that the Constitution guaranteed these legal outcomes to his homeland, Degetau embraced views held - and opposed - by many turn-of-thelast-century jurists: The Constitution constrained empire. Annexation accorded status and rights. A quarter century later, Degetau's contentions had lost decisively. Such views had ceased to be mainstream.

This Article proposes a new account of how empire became constitutional. It advances two interrelated claims. First, in 1898-but not twenty-five years later-U.S. citizenship appeared to many to promise Puerto Ricans numerous substantive rights and full inclusion of their homeland within the U.S. polity. Second, judges, administrators, and elected officials all contributed to these and related constitutional changes through a slow, tentative, and iterative process characterized by creativity and ambiguity. 
Several corollaries follow. As Degetau realized, and contrary to what has come to be the standard rendering, this sea change in constitutional thought was not the quick product of unilateral judicial action having little to do with citizenship. ${ }^{1}$ In contraposition to scholarship on the roles of judges and turn-ofthe-last-century administrators, the shift was also not the result of purely political dynamics divorced from courts, administration, and law. ${ }^{2}$ And contrary to what some work implies, it did not merely confirm what the Slaughter-House Cases (1873) had long before declared or made a fait accompli: the transformation of U.S. citizenship into a relatively inconsequential status. $^{3}$

These insights help solve the puzzle of how, despite a dearth of unambiguous, far-reaching Supreme Court holdings, conventional understandings of the constitutional order shifted away from according U.S. citizenship and robust rights to all nontribal U.S. people and toward acceptance of U.S. colonialism. Apparently presuming that such momentous legal changes trailed correspondingly important, new, and binding judicial statements, much work in the area seeks an elusive prize: dramatic holdings in the series of post1900 Insular Cases through which the Supreme Court addressed the status of newly acquired U.S. people and places. ${ }^{4}$ Other studies question whether law even factored in as a causal force in these and most other official matters. ${ }^{5}$ And it is conventional casebook wisdom that those like Degetau who brought early twentieth-century legal claims based on U.S. citizenship misperceived the status, which the Court had stripped of significance more than a decade before. ${ }^{6}$

This Article navigates these scholarly shoals in part by building upon recent work reasserting the prominent and complex roles of administration, courts, and law in the late nineteenth- and early twentieth-century United

1. See infra text accompanying notes 21,348 ; infra sources cited in note 96 ; infra notes 335 , 347, 356-64 and accompanying text.

2. In addition to elaboration of the point in the Introduction, see infra notes 48, 94, 127 and accompanying text.

3. See Slaughter-House Cases, 83 U.S. 36 (1873). On characterizations of the SlaughterHouse Cases as having largely foreclosed most claims predicated on U.S. citizenship, see, e.g., JESSE H. CHOPER, CONSTITUTIONAL LAW 354-61, 1321 (11th ed. 2011); RONALD D. ROTUNDA, MODERN COnStitutional LAW 479-85 (10th ed. 2012); Michael StOKes PAUlsen et AL., The CONSTITUTION OF THE UNITED STATES 930, 1333-1353 (2010); KATHLEEN M. SULLIVAN \& GERALD GUNTHER, CONSTITUTIONAL LAW 350-57 (17th ed. 2010); Minor v. Happersett, 88 U.S. 162 (1874); Maxwell v. Dow, 176 U.S. 581 (1900); McDonald v. City of Chicago, Ill., 130 S. Ct. 3020, 3028-31 (2010); Erman, supra note 15, at 162 ("The Slaughter-House Cases (1873) virtually nullified the Privileges and Immunities Clause."). On overstatements of the extent to which the Slaughter-House Cases represented judicial abandonment of former slaves, see PAMELA BRANDWEIN, RETHINKING THE JUDICIAL SETTLEMENT OF RECONSTRUCTION 53 (2011).

4. See infra notes 356-60.

5. See, e.g., Finley Peter DunNe, Mr. DOOLEY's OpinIONS 26 (1901) (making this point, via a fictional commentator, by writing "th' supreme coort follows th' iliction returns"); discussion within, text accompanying, and sources cited infra notes 8, 96; infra notes 94, 319-20, 349-50 and accompanying text.

6. See supra note 3. 
States. $^{7}$ The Article insists that the language of law structured exercises of power by officials throughout the federal government, that those exercises of power altered law, and that courts were but one among many state institutions contributing to the dynamic. ${ }^{8}$ Administrative entities were likewise important. Some agencies secured topflight legal talent who aimed to shape and follow the law in the myriad disputes that they were the first and sometimes only governmental bodies to adjudicate. ${ }^{9}$ This Article challenges scholars to show how courts, administration, and law interacted with each other and other state institutions to alter U.S. governance and constitutional meaning across time. ${ }^{10}$

7. On the need for the corrective, see, for example, Paul Frymer, Law and American Political Development, 33 L. \& SoC. INQUIRY 779 (2008) (arguing that American Political Development scholars have tended to underestimate the institutional nature of courts); Thomas M. Keck, Party Politics or Judicial Independence? The Regime Politics Literature Hits the Law Schools, 32 L. \& Soc. INQUIRY 511, 517 (2007) (arguing that Regime Theory scholars too often presume that governing coalitions dictate judicial results); Jerry L. Mashaw, Federal Administration and Administrative Law in the Gilded Age, 119 YALE L.J. 1362, 1365 (2010) (offering a corrective to American Political Development accounts of muscular administration only emerging in the 1930s); Reuel Edward Schiller, "Saint George and the Dragon": Courts and the Development of the Administrative State in Twentieth-Century America, 17 J. POL'Y HIST. 110 (2005) (noting the scarcity of American Political Development work concerning the judiciary); Keith E. Whittington, Once More Unto the Breach: PostBehavioralist Approaches to Judicial Politics, 25 L. \& SOC. INQUIRY 601, 613 (2000) (calling for a better understanding in American Political Development of how law influences judges); Bradley W. Joondeph, The Many Meanings of "Politics" in Judicial Decision Making, 77 U. Mo. Kan. CiTY L. REV. 347, 366-70 (2008). For work of an earlier vintage consistent with this newer scholarship, see, for example, Robert W. Gordon, Critical Legal Histories, 36 STAN. L. REV. 57 (1984) (refusing to separate law from society as a politics-driven model would require, and recognizing the autonomy of law); FrANCIS PAUL PRUCHA, THE GREAT FATHER (1984) (tracing extensive federal involvement in Indian affairs, including through administrative action). To avoid confusion as I examine the relationship of a Latin American place and people to the United States of America, I eschew the perhaps-familiar term "American state" in favor of the more specific "U.S. state."

8. See discussion within, text accompanying, and sources cited infra notes 8, 96; infra notes 94, 319-320, 349-50 and accompanying text. Decrying work portraying courts' actions as wholly derivative of other political forces, scholars associated with American Political Development have begun to call for work that brings law back into analyses in the ways described above. See, e.g., Frymer, supra note 7 (collecting sources).

9. Long before the New Deal, federal administration played numerous and powerful roles in the United States, including undertaking mass adjudications and developing extensive internal administrative law to guide their resolution. See Mashaw, supra note 7; see also, e.g., Andrew J. Polsky \& William D. Adler, The State in a Blue Uniform, 40 Polity 348 (2008); cf. DANIEL P. CARPENTER, THE FORGING OF BUREAUCRATIC AUTONOMY (2001) (tracing the rise of certain federal agencies during the Gilded Age); William J. Novak, The Myth of the "Weak" American State, 113 AM. HIST. REV. 752 (2008). For critical reviews of perceptions of federal administration as weak and lawless, see, for example, Desmond King \& Robert C. Lieberman, Finding the American State: Transcending the "Statelessness" Account, 40 POLITY 368, 370 (2008); Mashaw, supra note 7, at 1362 passim; cf. Reuel E. Schiller, Free Speech and Expertise: Administrative Censorship and the Birth of the Modern First Amendment, 86 VA. L. REV. 1 (2000) (describing administrative responsibility for speech regulation in the first half of the twentieth century).

10. See Sophia Z. Lee, Race, Sex, and Rulemaking: Administrative Constitutionalism and the Workplace, 1960 to the Present, 96 VA. L. REV. 799 (2010) [hereinafter Race, Sex, and Rulemaking]; Sophia Z. Lee, Hotspots in a Cold War: The NAACP's Postwar Workplace Constitutionalism, 19481964, 26 L. \& HIST. REV. 327 (2008); Gillian E. Metzger, Administrative Constitutionalism, 91 TEX. L. REV. 1897 (2013). 
The protagonist, period, and topic of this case study — Degetau's early twentieth-century struggles to secure U.S. citizenship for Puerto Ricans and the legacy of those struggles - are promising means through which to examine creation of Constitutional meaning by officials throughout the government. In 1898-1899, the United States took a deliberate turn toward empire by annexing first Hawai'i and then, following a war in which it invaded several Spanish imperial holdings, Puerto Rico, Guam, and the Philippines. ${ }^{11}$ Doing so raised hard questions about island constitutionalism, mainland constitutionalism, and their interrelationship. Within Puerto Rico, the change in sovereignty presaged a change in constitutional structure and derivative changes in rights, status, and self-government-perhaps, as Degetau hoped, bringing liberal reforms and home rule, and perhaps not.

On the mainland, the U.S. imperial turn brought debates over the compatibility of empire and the Constitution to the forefront of U.S. law and politics. ${ }^{12}$ Many mainlanders believed that the Constitution barred the United States from holding colonized U.S. peoples without extending them U.S. citizenship, full constitutional rights, and eventual statehood. Many others, and often the same people, believed that denying each of these rights to newly acquired populations was necessary to U.S. imperial success. The first halfdecade of the twentieth century was formative in establishing the ambiguous-

11. A century after the U.S. imperial turn, scholars have taken a similar turn toward empire. For an early example, see AMY KAPLAN, THE ANARCHY OF EMPIRE IN THE MAKING OF U.S. CULTURE (2002). No such turn was required for scholars already working on U.S. territories acquired by the United States in 1898, see, e.g., Foreign IN A DOMESTIC SENSE (Christina Duffy Burnett \& Burke Marshall eds., 2001); José Trías Monge, Puerto Rico: The TRIals of the Oldest COLONY IN THE WORLD (1997), which included work on links between race, empire, and law, see, e.g., José A. Cabranes, Puerto Rico: Colonialism as Constitutional Doctrine, 100 HARV. L. Rev. 450, 455-58 (1986) (reviewing JuAN R. TORRUElla, The Supreme COURT AND PuERTO Rico: ThE Doctrine of SeParate and Unequal (1985) [hereinafter The Supreme Court and Puerto RICO]). On prior U.S. expansion, conquest, and territorial governance, see, for example, JACK ERICSOn Eblen, The FirST AND SeCONd United States EMPIRES (1968); Sarah H. Cleveland, Powers Inherent in Sovereignty: Indians, Aliens, Territories, and the Nineteenth Century Origins of Plenary Power over Foreign Affairs, 81 TEX. L. REV. 1 (2002). On 1897-99 as an imperial turn, see, for example, BARTHOLOMEW H. SPARROW, THE INSULAR CASES AND THE EMERGENCE OF AMERICAN EMPIRE 3-9, 40 (2006); JuAN R. TORRUElla, Global InTRIGUES (2007) [hereinafter Global INTRIGUES]; Walter Lafeber, The "Lion in the Path": The U.S. Emergence as a World Power, 101 PoL. SCI. Q. 705 (1986); Adlai E. Stevenson et al., Bryan or McKinley? The Present Duty of American Citizens, 171 N. AM. REV. 433 (1900) (arguing from an anti-imperialist/Democratic perspective that then-contemporary imperialism was altogether new to the United States). On the nearly three-decade halt in U.S. expansion following ratification of the Fourteenth Amendment, see Downes v. Bidwell, 182 U.S. 244, 304-05, 319-37 (1901) (White, J., concurring); Treaty of Peace, U.S.-Spain, Dec. 10, 1898, 30 Stat. 1754, 1755 (Puerto Rico, Guam, and the Philippines); H.R.J. Res. No. 55, 55th Cong. (1898) (Hawai 'i); Jon M. Van Dyke, The Evolving Legal Relationships Between the United States and Its Affiliated U.S.-Flag Islands, 14 U. HAW. L. REV. 445, 493-94 (1992) (describing extension of U.S. sovereignty over Samoa in 1899-1929).

12. See Van Dyke, supra note 11, at 493-94. 
yet-subordinate place of the new possessions of the United States in its constitutional system. ${ }^{13}$

During the period, as he campaigned to be Resident Commissioner and then discharged the office, Degetau studied and joined constitutional debates concerning newly acquired U.S. people and places. In Washington, this brilliant lawyer and keen, engaged observer of legal-political interactions among state actors steeped himself in questions of Puerto Rican status and rights. He brought a fluid and experimental approach to his advocacy of U.S. citizenship for Puerto Ricans, exploiting opportunities as they arose. His efforts tested the bounds of varied federal officials' ability and willingness to recognize his countrymen as fellow citizens.

Degetau knew well that the state with which he interacted was not one solely dominated by, in Stephen Skowronek's memorable phrase, "courts and parties." 14 Judges, administrators, presidents, and congressmen all played roles in constitutional change and adjudication. ${ }^{15}$ Individuals in each group noted how their colleagues elsewhere in the state addressed constitutional questions arising out of the U.S. imperial turn. And actors within all these groups addressed such questions themselves. ${ }^{16}$ Constrained by an official landscape

13. See, e.g., SPARROW, supra note 11. For works focused on Puerto Rico, see, for example, Pedro A. Cabán, Constructing a Colonial People (1999); Foreign in a Domestic Sense, supra note 11; EFRÉN RIVERA RAMOS, THE LEGAL CONSTRUCTION OF IDENTITY (2001); Torruella, The Supreme Court and Puerto Rico, supra note 11; Christina Duffy Burnett, Untied States: American Expansion and Territorial Deannexation, 72 U. CHI. L. REV. 797 (2005); José A. Cabranes, Citizenship and the American Empire: Notes on the Legislative History of United States Citizenship of Puerto Ricans, 127 U. PA. L. REV. 391 (1978).

14. Skowronek observed the uneven influence of administrative institutions in this period when he introduced the courts-and-parties formulation in Building a New American State (published in 1982). On the nonetheless enduring influence of the concept as an impediment to perceiving the full scope of administrative influence in the U.S. state, see, for example, Richard R. John, Rethinking the Early American State, 40 POLITY 332 (2008).

15. Cf. Reuel E. Schiller, Rulemaking's Promise: Administrative Law and Legal Culture in the 1960s and 1970s, 53 ADMIN. L. REV. 1139 (2001) (making a similar point about administrative law). On the importance of legal thinking throughout the U.S. state, see, for example, KEITH E. WhitTington, Political Foundations of Judicial Supremacy 52 passim (2007) (casting constitutional reconstruction as a key task for presidents establishing new political regimes); Novak, supra note 9, at 767-68 (2008) (collecting sources); Daniel R. Ernst, Ernst Freund, Felix Frankfurter, and the American Rechtsstaat: A Transatlantic Shipwreck, 1894-1932, 23 STUD. AM. POL. DEV. 171 (2009); Daniel R. Ernst, Dicey's Disciple on the D.C. Circuit: Judge Harold Stephens and Administrative Law Reform, 1933-1940, 90 GEO. L.J. 787 (2002); John Fabian Witt, Law and War in American History, 115 AM. HIST. REV. 768, 769-70 (2010); Samuel C. Erman, Puerto Rico and the Promise of United States Citizenship: Struggles around Status in a New Empire, 1898-1917, at 31-35, 148, 153 (2010) (unpublished Ph.D. dissertation, University of Michigan), available at http:/hdl.handle.net/2027.42/75920 (elaborating examples below).

16. In addition to the instances detailed below, see Erman, supra note 15, at 1-195. Compare, e.g., Gordon Silverstein, Law's Allure in American Politics and Policy: What It Is, What It Is Not, and What It Might Yet Be, 35 L. \& SOC. INQUIRY 1077, 1080, 1089 (2010) (arguing that state actors may act in conjunction without consciously cooperating), with WHITTINGTON, supra note 15, at 98-100 (describing how elected federal officials may signal their desires to courts), and Luke M. Milligan, Congressional End-Run: The Ignored Constraint on Judicial Review, 45 GA. L. REV. 211 (2010) 
that they could also alter, they thus exercised bounded autonomy in addressing constitutional disputes. ${ }^{17}$

Though often overlooked by existing scholarship, U.S. administrators were among the crucial agents of early twentieth-century constitutional changes concerning U.S. empire. Through adjudicating disputes over Puerto Rican rights, they created potential judicial test cases. And they modeled - and altered the stakes of-various approaches the Court could take to judge the constitutionality of U.S. empire. In some instances, they proposed legal underpinnings for U.S. empire that came to be reflected in Supreme Court doctrine. $^{18}$

Degetau's activities and networks also reveal lost legal transformations. Most immediate is that of U.S. citizenship, which Degetau relentlessly sought for Puerto Ricans in 1900-1905. At the dawn of the twentieth century, U.S. citizenship was a consequential status, though also an embattled one. Jurists throughout and beyond the federal government trumpeted its importance, insisted upon its broad distribution within the states, and sought and discussed the many sub-constitutional rights that attached to it, even as they recognized the paucity of judicially enforceable constitutional rights that it carried. Perceived by many to be too substantive for Puerto Ricans immediately after 1898 , U.S. citizenship had come to be referred to as a "perfectly empty gift" by the time the political branches naturalized Puerto Ricans but not Filipinos in 1916-1917. ${ }^{19}$

Somewhat counterintuitively, recognition that courts lacked sole responsibility for legal change reveals the importance of to-dateunderemphasized cases, doctrines, and judicial acts. For example, Gonzales v.

(similar); $c f$. Silverstein, supra, at 1080 ("[T]o fully appreciate and understand how law shapes and constrains politics and policy, we have to consider the iterated interaction between and among these institutions ...."). Variations on this question are longstanding in legal history. See, e.g., Gordon, supra note 7. For more recent works along these lines, see, for example, Frymer, supra note 7, at 794, 782 (reviewing work arguing that "no one paradigmatic understanding of judicial decision making can independently explain the Court's logic" and seeking new inquiries into the relationship between an institutional understanding of courts and how "courts play an often central and vital role in enhancing the power of the modern state").

17. On institution-level differences in approaches to law, see WHITTINGTON, supra note 15, at 14-18, 22-23, 52, 287; Joondeph, supra note 7, at 359-60 passim; Keck, supra note 7, at 532; Milligan, supra note 16, at 245-48, 273 (collecting sources); Mark A. Graber, Looking Off the Ball: Constitutional Law and American Politics 35 (2007) (unpublished manuscript), available at http://digitalcommons.law.umaryland.edu/fac pubs/381/.

18. For other works along these lines, see Anuj C. Desai, Wiretapping Before the Wires: The Post Office and the Birth of Communications Privacy, 60 STAN. L. REV. 553 (2007) (suggesting that federal legislation and administrative practice lay foundations for modern Fourth Amendment jurisprudence); Lee, Race, Sex, and Rulemaking, supra note 10, at $809 \&$ n.23 (collecting sources "focused exclusively on the work of the President's closest legal advisors"); Schiller, supra note 9 (variously describing instances of administrative regulations of speech being supplanted by and surviving judicial regulation under the First Amendment).

19. Letter of Secretary Post, July 7, 1905, in S. REP. NO. 59-2746, at 2 (1906). 
Williams, ${ }^{20}$ an Insular Case in which Degetau participated as amicus curiae, illustrates how the Justices were but one among several sets of actors contributing to the slow decline in the promise of U.S. citizenship for Puerto Ricans. Today, the Insular Cases are best known for introducing into U.S. law the still-binding doctrine of territorial nonincorporation, which marks some U.S. possessions as not necessarily destined for statehood and deprives those resident there of constitutional protection of nonfundamental rights. ${ }^{21}$ In Gonzales, a unanimous Court settled another controversy, holding that Puerto Ricans were not aliens, hence not subject to immigration laws, while reserving the harder question of whether they were U.S. citizens. This reservation unsettled the presumption that citizenship was identical to non-alienage, a presumption that many early twentieth-century administrative and judicial officials and claimants shared with Degetau. The Court's evasion by concession signaled to many that U.S. citizenship would come to Puerto Rico, if at all, via the political branches. And as numerous other federal officials also evaded claims to citizenship by extending islanders various rights, the number of benefits that Puerto Ricans could expect to secure from naturalization shrank.

The Gonzales decision thus came to matter because of its contribution to interrelated processes of constitutional change and colonial governance already unfolding across diverse parts of the U.S. state. Proceeding as one-albeit unique-legal and political actor among many, the Gonzales Court combined creativity and ambiguity to facilitate U.S. empire without explicitly altering the constitutional law of U.S. citizenship. ${ }^{22}$

As we will see, recognizing this dynamic in Gonzales points the way to a wider reinterpretation of the Insular Cases. On most scholarly accounts, the Supreme Court in 1901-1905 issued broad holdings that laid the constitutional foundations for U.S. empire. ${ }^{23}$ But as Gonzales illustrates, the Supreme Court did not always rush into the breach. Rather, through evasions, it sometimes also created space for nonjudicial federal officials to maneuver and innovate. ${ }^{24}$ This suggests that Gonzales and the Insular Cases more generally may be best

20. Gonzalez v. Williams, 192 U.S. 1 (1904).

21. See infra notes 335, 347-48, 356-65 and accompanying text. For works defining and listing Insular Cases, see, for example, SpARRow, supra note 11; Christina Duffy Burnett, A Note on the Insular Cases, in FOREIGN IN A DOMESTIC SENSE, supra note 11, at 389.

22. Cf. WhitTington, supra note 15 , at 72 (suggesting that general articulations of constitutional visions by the Supreme Court may at times be of more moment than the specific judgments that it issues); Novak, supra note 9, at 767-68 (observing how law is a creative source of power that operates both within and beyond courts). But cf. Cass R. Sunstein, Beyond Judicial Minimalism, 43 TULSA L. REV. 825, 839 passim (2008) (implicitly placing judicially minimalistic reasoning and holdings in opposition to judicial activism).

23. See infra text accompanying notes 368 , 371; infra notes $335,347-48,356-68,369$ and accompanying text.

24. On policymakers implementing policies iteratively in interaction with courts rather than risking repeated reversals, see, for example, Silverstein, supra note 16, at 1080-84, 1087-92. 
understood as part of an iterative, joint process of constitutional change that spanned the federal government, unfolded across decades, and proceeded through creative ambiguity. ${ }^{25}$ Confirming and detailing the mechanics of this process is grist for another project. This Article seeks to bring its broad contours into view: as I discuss at greater length in the Conclusion, close study of what Degetau did, saw, and helped set in motion both demonstrates the close relationship between officials' shared commitments to law and processes of constitutional change and uncovers particular official acts that set such change in motion.

This Article proceeds in five Parts. Part I sketches Degetau's background and then traces his and certain U.S. officials' responses to consolidation in 1898-1900 of U.S. rule in Puerto Rico. Those responses unfolded in the shadow of the Constitution, and Degetau's response included his development of a theory aimed at reconciling major strands of U.S. and Puerto Rican thought on constitutionalism. Part II provides a brief account of relevant aspects of the 1901 Insular Cases, the Court's first major-and still-ambiguous - statement on the constitutional implications of the U.S. imperial turn of 1898-1899. In Part III, Degetau returns to center stage for his inaugural term (1901-1902) as his island's first elected representative in Washington as Resident Commissioner. In this role, he sought to win acceptance for his ideas among U.S. administrative officials and others. Degetau turned to the courts in 19021905, as Part IV relates, launching efforts that notably included the 1904 Supreme Court case of Gonzales v. Williams. Part V surveys the largely nonjudicial fights over Puerto Rican status in the years after Degetau's term ended in 1905, noting how prior judicial decisions shaped those battles, the outcomes of which courts eventually confirmed. The study concludes with observations on relationships between law and U.S. empire, on meanings of the Insular Cases, and on how officials' shared commitments to law and particular of their interactions with each other drove instances of early twentieth-century U.S. constitutional change.

I.

\section{U.S. RULE IN THE SHADOW OF THE CONSTITUTION, 1898-1900}

Degetau's trajectory from second-class member of the Spanish Empire to relentless advocate of U.S. citizenship for all Puerto Ricans proceeded in

25. See infra text accompanying, discussion within, and source cited in note 371; infra notes notes 104, 335, 347-48, 356-68 and accompanying text; compare TRÍAS MONGE, supra note 11, at 457 (noting that the Insular Cases, for instance, lay groundwork for muscular U.S. imperial rule in Puerto Rico), with Burnett, supra note 11, at 838 (noting that for at least one purpose the Insular Cases treated Puerto Rico - as compared to traditional U.S. territories - more like a state of the union), and Sanford Levinson, Why the Canon Should be Expanded to Include The Insular Cases and the Saga of American Expansionism, 17 CONST. COMMENT. 241, 261 (2000) (noting ways that the Insular Cases created greater potential space-vis-à-vis traditional U.S. territories-for multiculturalism-based innovations). 
stages. As a young man, he became immersed and prominent in a political movement seeking liberal reforms and autonomy for Puerto Rico. U.S. invasion and annexation of his island then provided him new opportunities to realize these ends. He came to believe that pursuit of U.S. citizenship was the key to achieving them. His focus on U.S. citizenship then persisted, even as some U.S. officials and jurists came to quite different conclusions.

Degetau began his life amidst liberalism and bondage. His parents hosted meetings of leading liberals in their home, their western-European and Puerto Rican relatives included abolitionists, and his father died owning a young man named Chalí as a slave. ${ }^{26}$ As a Puerto Rican native, Degetau was also part of a population that held an intermediate status within imperial Spain. Spain favored its citizens born on the Iberian Peninsula over those of island birth. And in the years after Degetau's birth, Spain only sometimes extended Puerto Ricans full constitutional rights and proportionate national-level representation. ${ }^{27}$

Consonant with his emerging status as a Puerto Rican gentleman, Degetau earned a law degree in continental Spain in 1888 and cultivated liberal causes and associates. He thus joined a liberal-republican Puerto Rican political party known as the Partido Autonomista, which sought greater individual civil and political liberties and island autonomy from Spain. ${ }^{28}$ More mercenarily, these largely island-born men also hoped to end preferences for natives of the Iberian Peninsula in appointments to official posts on the island. ${ }^{29}$ The Partido Autonomista fractured in 1898 over whether to ally with a monarchical Spanish party willing to support Puerto Rican autonomy. ${ }^{30}$ As a rising star in the party named Luis Muñoz Rivera and other former co-partisans of Degetau's

26. See Ángel M. Mergal, Federico Degetau 30-34 (1944); Untitled document (May 27, 1864), CIHCAM 6/VII/14.

27. See, e.g., TríAS Monge, supra note 11, at 10-13; DAVID ORTIZ, JR., PAPER LiBERALs $21-$ 22 (2000) (describing patronage practices in Spain and their extension to the colonies); Astrid CubanoIguina, Political Culture and Male Mass-Party Formation in Late-Nineteenth-Century Puerto Rico, 78 HISP. AM. HIST. REV. 631, 641-43 (1998) (describing development of a patronage system within Puerto Rico dominated by those born on the Iberian Peninsula); see also, e.g., Scott C. James, Patronage Regimes and American Party Development from 'The Age of Jackson' to the Progressive Era, 36 BRIT. J. POL. SCI. 39 (2005); Memorandum from George R. Colton, Insular Collector of Customs, to Clarence R. Edwards, Chief of the Insular Bureau (Mar. 1, 1910), MD NARA 350/5A/341/3377-49; Memorandum from George R. Colton, Insular Collector of Customs, to Clarence R. Edwards, Chief of the Insular Bureau (Mar. 2, 1910), MD NARA 350/5A/341/3377-57.

28. See Mergal, supra note 26, at 39-46; TRÍAs MONGE, supra note 11, at 11; Copy, Certificate of Federico Degetau Upon Receiving His Law License (Oct. 29, 1888), in A. M. Melgar, Documentación relacionada con la vida y la obra de D. Federico Degetau, 1941, 29, CIHCAM 20/L2. Degetau moved in liberal circles, including by advocating mandatory international arbitration and discussing death-penalty abolition with Victor Hugo. See Delegate from Porto Rico, TIMES, Worthington, Ind., [Dec. 1900?], CIHCAM 22/L1, at 107; see also Certification of Membership in El Porvenir (Jan. 20, 1882), CIHCAM 6/VII/16; MERGAL, supra note 26, at 43-46.

29. See Sam Erman, The Reconstruction Constitution in the Age of Empire [hereinafter Reconstruction and Empire] 17-19 (Aug. 10, 2013) (unpublished manuscript) (on file with author).

30. GONZALO F. CÓRDOVA, RESIDENT COMMISSIONER SANTIAGO IGLESIAS AND His TimeS 26-27, 31, 33-37, 53-55 (1993). 
embraced the alliance, Degetau split off to form a competing political organization. ${ }^{31}$ In the elections that followed in early 1898, Degetau's new opponents won handily, installing Muñoz Rivera at the head of the cabinet-like island Council of Secretaries. ${ }^{32}$ U.S. troops arrived on July 25, 1898.

The looming U.S. annexation brought Puerto Rico into a United States riven by race and just coming to identify as imperial. ${ }^{33}$ While this Article does not seek to define empire or race (relying instead on historical actors' unstated intuitions and conventional language), some preliminary observations will illuminate the questions that the Article does tackle. ${ }^{34}$ First, despite differences

31. FERnANDo BAyron TORO, EleCCIONES y PARTIDOS POLITICOS DE PUERTO RICO 10708 \& n.153 (1977); CóRDOVA, supra note 30, at 26-27, 31, 33-37, 53-55, 60; id. at 54 (explaining that Degetau's alliance continued to support the principles of the Partido Autonomista); TRÍAS MONGE, supra note 11, at 11-15; Untitled Document (Oct. 22, 1898), AG/DE/SPR/COS, C.F. 74, D.P., 1898 (Luis Muñoz Rivera accepting appointment as Secretary of State and President of the Council of Secretaries in San Juan); Letter from José Barbosa to Federico Degetau (July 11, 1898), CIHCAM 2/III/93.

32. BAYRON TORO, supra note 31, at 107-08 \& n.153; Geo W. Davis, Report of Brig. Gen. Geo. W. Davis, U.S.V., on Civil Affairs of Puerto Rico, in 1 ANNUAL REPORTS OF THE WAR DEPARTMENT FOR THE FISCAL YEAR ENDED JUNE 30, 1899, at 8-10 (1899). The election resulted when, following the schism between Muñoz Rivera's faction and that of Degetau, Muñoz Rivera's allies in Spain came to power and extended Puerto Rico relatively broad autonomy. After having secured those gains, Muñoz Rivera and his allies were able to win a resounding victory in 1898 over Degetau's faction, which secured just 20 percent of the vote. See, e.g., Erman, supra note 15, at 21-22, 49-50.

33. On racial views of U.S. administrators and politicians and their relationships to the policies that they adopted, see, for example, Paul A. Kramer, The BloOd OF Government (2006) (discussing the Philippines); LOUIS A. PÉREZ, JR., CUBA BETWEEN EMPIRES 1878-1901 (1983); PRUCHA, supra note 7 (discussing U.S.-American Indian relations); Cabranes, supra note 13 (discussing Puerto Rico); Lanny Thompson, The Imperial Republic: A Comparison of the Insular Territories under U.S. Dominion after 1898, 71 PAC. HIST. REV. 535 (2002). On similar dynamics involving Supreme Court justices and their decisions concerning U.S. imperial holdings, see, for example, MARK S. WEINER, AMERICANS WITHOUT LAW 67-77 (2006); Erman, supra note 15, at 98100; Juan F. Perea, Fulfilling Manifest Destiny: Conquest, Race, and the Insular Cases, in ForEIGN IN A DOMESTIC SENSE, supra note 11, at 140; infra note 112 and accompanying text. See also PAUL T. MCCARTNEY, POWER AND PROGRESS (2006) (tackling relationships of social Darwinism, race, religion, constitutionalism, and empire); Erman, Reconstruction and Empire, supra note 29 (discussing the views and choices of justices, other U.S. officials, and key Puerto Rican political leaders); Rogers M. Smith, The Bitter Roots of Puerto Rican Citizenship, in FoREIGN IN A DOMESTIC SENSE, supra note 11, at 373, 376-79 (observing the role of racial thinking in legal debates over empire).

34. These matters merit and have received much fuller treatment in work that makes them its focus. See, e.g., Sam Erman, Meanings of Citizenship in the U.S. Empire: Puerto Rico, Isabel Gonzalez, and the Supreme Court, 1895 to 1905, 27 J. AM. ETHNIC HIST. 5 (2008) (focusing, inter alia, both on contemporary views of Puerto Rican racial character that differed from those that Degetau advanced and on the elisions and manipulations that Degetau deployed in portraying leading Puerto Rican men as white); Erman, supra note 15 (similar); Erman, Reconstruction and Empire, supra note 29 (similar). For a sample of scholarship making progress on interrelationships between race, legal policy, and empire, see KRAMER, supra note 33 (investigating the relationship between U.S. racial thinking and U.S. policy in the Philippines); Thompson, supra note 33 (examining how perceived racial differences among colonized U.S. peoples resulted in differential official treatment); Mark S. Weiner, Teutonic Constitutionalism: The Role of Ethno-Juridical Discourse in the Spanish-American War, in FOREIGN IN A DOMESTIC SENSE, supra note 11, at 48-49 (describing recourse to concepts of Anglo-Saxon superiority in congressional and Supreme Court decision making). 
over what empire meant and whether it was desirable, ${ }^{35}$ a broad consensus existed in the turn-of-the-last-century United States that the most recent U.S. annexations were newly imperial in nature (in purported contrast to previous U.S. acquisitions). ${ }^{36}$ Second, U.S. racial schemas also differed from those in Puerto Rico and in other new U.S. possessions. In pre-annexation Puerto Rico, for instance, men recognized as of European descent (like Degetau) had occupied top rungs in the social order. Following annexation, mainland U.S. public opinion often deprecated all Puerto Ricans as racially mixed regardless of the self-proclaimed status of many political leaders there as "sons of Spain." ${ }^{37}$ To the extent that the U.S. public accepted leading Puerto Rican men's presentations of themselves as essentially Spanish, it still often perceived such islanders to be a darker shade of pale than its increasingly Anglo-Saxon measure of whiteness. ${ }^{38}$

35. See supra note 11.

36. See, e.g., Robert L. Beisner, Twelve Against Empire ix-xvi \& n.*, 220, 222 (1968); sources cited supra note 35 . Among mainlanders' reasons for holding this view were several perceived distinctions between the expansions of 1898-99 and those that had preceded them: the most recent expansions caused other empires to treat the United States as a peer. In governing the new U.S. lands, U.S. officials explicitly looked to other empires' practices - as models and negative examples. See, e.g., CABÁN, supra note 13, at 2, 58 (United States borrowing from other empires); PHILIP C. JESSUP, 1 ELIHU ROOT 345 (1938) (discussing Root's attempts to construct a distinctly U.S. empire); TORRUELLA, GLOBAL INTRIGUES, supra note 11 (U.S. emergence as an imperial power). The new possessions were not contiguous with the United States or reachable from it by land; many lay quite far from the mainland. See, e.g., Downes v. Bidwell, 182 U.S. 244, 281-82 (1901) (Brown, J.). A temporal break of three decades separated 1898-99 from the last major U.S. territorial expansion. See Erman, Reconstruction and Empire, supra note 29, at 3 (discussing implications of this pause in U.S. expansion). The recently annexed people formed large, dense, and racially suspect populations. See, e.g., Frederic R. Coudert, Jr., Our New Peoples: Citizens, Subjects, Nationals or Aliens, 3 Colum. L. REV. 13, 13-14 (1903). And it was not clear that the newly U.S. lands would become states or that the newly U.S. people would become U.S. citizens. See, e.g., SPARROW supra note 11, at 5, 41-53 (summarizing contemporary legal-academic debates).

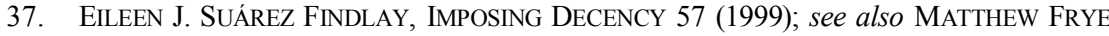
JACOBSON, BARBARIAN VIRTUES 240-41 (2000) (highlighting Congressional statements describing Puerto Ricans as of a "wholly different character" and an "entirely unassimilable [sic] people"); JOHN. J. JOHNSON, LATIN AMERICA IN CARICATURE 161, 163, 173, 217 (1980) (reprinting U.S. cartoons depicting Puerto Ricans as racial inferiors). Other Puerto Ricans - including some early political leaders - at times rejected their colleagues' claims to whiteness. Aware that Muñoz Rivera was closely associated with the "sons of Spain" formulation, for instance, Republicano leader of color José Celso Barbosa, discussed infra note 44 and in accompanying text, sought electoral advantage following the end of Spanish rule by criticizing Muñoz Rivera and his partisans as a party of los blancos (the whites) who acted in the interests of los españoles (the Spaniards). Miriam Jiménez Román, Un hombre (negro) del pueblo: José Celso Barbosa and the Puerto Rican "Race" Toward Whiteness, 8 CENTRO 8, 17 (1996). Here, Barbosa contemplated islanders of color playing central roles in the leadership and electorate of Puerto Rico. Though Degetau and Barbosa were members of the same island political party, Degetau more steadfastly portrayed Puerto Rican leaders as essentially white.

38. On the concept of the "Anglo-Saxon" and its relationship to scientific racism and U.S. white mainstream thought on American Indians and Filipinos, see, for example, Weiner, supra note 34. On perceived racial differences among those of European descent, see MATTHEW FRYE JACOBSON, WHITENESS OF A DIFFERENT COLOR (1998). For overviews of the triumph among mainstream whites of a white-supremacist ideology that embraced a tragic legend of Reconstruction and of related processes of black disfranchisement and imposition of Jim Crow regimes, see, for 
As Degetau quickly perceived, the U.S. invasion also hit politics on the island like a hurricane, variously washing away, leaving unscathed, and wholly upending aspects of the landscape. Concern with Spanish policies had disappeared. Muñoz Rivera's and Degetau's competing political alliances emerged largely intact. ${ }^{39}$ And the United States took center stage as an object of and participant in island debates.

Though U.S. military officials had initially reconstituted the Council of Secretaries, on February 6,1899, they ordered its heads to report directly to U.S. military governor Guy Henry. ${ }^{40}$ Muñoz Rivera and his colleagues resigned in protest and unavailingly appealed to Washington. ${ }^{41}$

Muñoz's setbacks facilitated gains by Degetau, who secured a vacancy as one of four top civilian officers on the island. ${ }^{42}$ When Spain and the United States formalized the U.S. annexation of Puerto Rico via the Treaty of Paris, Degetau and his co-partisans reconstituted themselves into a new political party, which they called Republicano. ${ }^{43}$ Doing so reflected and sought to extend their alignment with mainland Republicans and, as a result of Republicans' commitment to U.S. retention of Puerto Rico, with an empirestate that many islanders perceived to be a modern and affluent model of democracy. José Celso Barbosa - a prominent man of color in Puerto Rico who had experienced Republican politics in the 1870s while on the mainlandheaded the Partido Republicano, which also found in the alliance an opportunity to align with progressive Republicans and against Democratic segregationists. ${ }^{44}$ Muñoz Rivera and his allies soon reorganized themselves into the Partido Federal. ${ }^{45}$

example, DAVID W. BLIGHT, RACE AND REUNION (2001); BRANDWEIN, supra note 3, at 7, 10, 184 86; MARK Elliott, COlor-Blind Justice 248 (2006); REBECCA J. SCOTT, DEGREES OF FreEDOM 87, 195-97, 200, 259 (2005); C. VANN WoOdWARD, ORIGINS OF THE NEW SOUTH, 1877-1913, at 322 (Stephenson \& Coulter eds., 2000); Richard H. Pildes, Democracy, Anti-Democracy, and the Canon, 17 Const. Comment. 295, 301-02 \& n.29 (2000); Rebecca J. Scott, Public Rights, Social Equality, and the Conceptual Roots of the Plessy Challenge, 106 MiCH. L. REV. 777 (2008).

39. CóRdOVA, supra note 30, at 65. Degetau, consequently, remained associated with the political party that had decisively lost the most recent island-wide election.

40. Laws, Ordinances, DeCrees, and Military ORders Having the Force of LaW, EFFECTIVE IN PUERTO RiCO, H.R. DOC. NO. 60-1484, at 2191-92 (1909).

41. CABÁN, supra note 13, at 167; HEADQUARTERS DEP'T OF P.R., GENERAL ORDER No. 17, FEB, 10, 1899, reprinted in 1 ANNUAL REPORTS OF THE WAR DEPARTMENT FOR THE FISCAL YEAR ENDED June 30, 1899, at 576 (1900); Muñoz Rivera en los Estados Unidos, LA DEMOCRACIA, May 3, 1899 , at 2.

42. HeAdQuarters DeP’T OF P.R., General ORder No. 15, Feb. 9, 1899, in H.R. Doc. No. 60-1484, at 2193 (1909).

43. See Treaty of Peace, supra note 11; F. Degetau y GonZalez, To the PeOPle / Al País [1899?], CIHCAM 22/L1.

44. See Erman, Reconstruction and Empire, supra note 29, at 18 passim. Although those who favored Republican expansionism often spoke in terms of the white man's burden, see Thomas R. McHale, American Colonial Policy Towards the Philippines, 3 J. S.E. ASIAN HIST. 24, 34-35 (1962) (quoting President McKinley), it was anti-imperialists and Democrats who tended to make the harshest comments concerning the racial characters of the newest U.S. peoples, see, e.g., Erman, 
Throughout 1899, Degetau built on his reputation by mastering English and developing expertise in U.S. law and politics. ${ }^{46}$ As he was well positioned to see, debates during these months continued to rage in the United States over constitutional meanings of U.S. empire and the fitness of newly acquired peoples like Puerto Ricans - and especially Filipinos ${ }^{47}$ - for self-government and U.S. membership. ${ }^{48}$

While the McKinley administration moved ahead with imperial governance, self-described anti-imperialists mobilized half a million American "contributors" and powerful spokespeople in opposition. They perceived imperialism to violate the Constitution and transgress U.S. liberal-democratic ideals. Perhaps most importantly to many of them, they also saw the policy as a threat to the U.S. racial order. ${ }^{49}$ Their efforts failed to block formal annexation of formerly Spanish lands, but did secure a Senate Resolution declaring that the body did "not intend[] to incorporate the inhabitants of the Philippines into citizenship of the United States." 50

Jurists during this period struggled to reconcile the potentially colonial U.S. imperial turn with Reconstruction-era legal developments that many still saw as embodying more egalitarian principles. ${ }^{51}$ For nearly three decades following ratification of the Reconstruction Amendments, U.S. territorial expansion had stopped. ${ }^{52}$ As a result, the status of newly annexed people under those Reconstruction Amendments remained an open and untested question. It was possible - and controversial - to argue in 1898 that the Fourteenth and Fifteenth Amendments and the Constitution that they modified made all nontribal U.S. peoples, including those of color, both U.S. citizens with substantive privileges and immunities and citizens of a state or of a territory on the road to

Reconstruction and Empire, supra note 29; infra note 186 and accompanying text. For descriptions of Barbosa as a man de color (of color), see, for example, SANTIAGO IGLESIAS PANTín, 1 LUCHAS EMANCIPADORAS (CRONICAS DE PUERTO RICO) 59 (2d ed. 1958 [1929]). Barbosa himself used the phrase, describing his as the "party of the men of color." FINDLAY, supra note 37, at 142-43 (quoting, inter alia, the newspapers La Defensa and El Águila).

45. Programa del Partido Federal 10 [1899?], CIHCAM 6/L3.

46. F. Degetau y Gonzales, Antecedentes del debate: I. Economicos, El PAís, Mar. 4, 1900, CIHCAM 18/L2; La constitución Americana: conferencia de Degetau, El PAís, Apr. 17, 1900, CIHCAM 12/L2; F. Degetau y Gonzalez, Educacion civica, Parts I-VI, paper unknown, [Aug. 1900?], CIHCAM 12/L2; Letter from Federico Degetau to Adolfo Marin [Spring 1899?], CIHCAM 2/IV/13.

47. See, e.g., Cabranes, supra note 13, at 420-25, 429-32; Allen H. Merriam, Racism in the Expansionist Controversy of 1898-1900, 39 PHYLON 369 (1978).

48. On using constitutional idioms to justify empire, see JOHN HART ELY, WAR AND RESPONSIBILITY 11 passim (1993) (analyzing the constitutionality of the U.S. war in Indochina with a focus on political events and justifications); Juan R. Torruella, The Insular Cases: The Establishment of a Regime of Political Apartheid, 29 U. PA. J. INT’L L. 283, 284-85 (2007).

49. BEISNER, supra note 36, at 216, 219-20, 225.

50. McEnery Resolution Adopted, L.A. TIMES, Feb. 15, 1899, at 2.

51. On relationships between U.S. empire and legacies of the Civil War, see BLIGHT, supra note 38, at 291, 352-56, 472 n.24; SCOTT, supra note 38, at 154-88; WOODWARD, supra note 38, at 324-25; Levinson, supra note 25, at 257-59.

52. See supra note 11. 
statehood. ${ }^{53}$ For their part, Supreme Court justices treated citizenship ambivalently, variously celebrating its significance, ${ }^{54}$ reaffirming its broad distribution within the states of the Union, ${ }^{55}$ and construing it to provide few justiciable constitutional rights. ${ }^{56}$ Against this backdrop, U.S. jurists also disagreed over legal legacies of the Civil War and their applicability to U.S. empire. Some asserted that following annexation Puerto Ricans would secure U.S. citizenship, eventual statehood, and full constitutional protections all in a bundle. ${ }^{57}$ Others claimed that these three legal changes would not reach Puerto Ricans at all. ${ }^{58}$

Federal administrators also variously weighed in on both sides. After extensive firsthand study of conditions in Puerto Rico, Henry Carroll, Special Commissioner for the United States to Porto Rico, recommended to the president that Puerto Ricans be made U.S. citizens with full constitutional rights and a traditional form of territorial government that would include a fully elected legislative branch. ${ }^{59}$ Charles Magoon went further. He was the law officer for what came to be the Bureau of Insular Affairs in the War Department, the bureau with jurisdiction over Puerto Rico in the months after the U.S. invasion. In mid-1899, he opined that annexation had made the territory "a part of the United States, and, as such, subject to the Constitution." 60

After becoming Secretary of War in August 1899, the prominent Republican Wall Street lawyer Elihu Root rejected such generous approaches to Puerto Rican status and rights. ${ }^{61}$ In Puerto Rico, he insisted, governance, and hence the U.S. imperial experiment, "would inevitably fail without a course of

53. For more on this point, see Erman, Reconstruction and Empire, supra note 29, at 11 passim. See also Lisa Maria Perez, Citizenship Denied: The Insular Cases and the Fourteenth Amendment, 94 VA. L. REV. 1029, 1052-56 (2008).

54. The dynamic continued after 1898. See, e.g., Downes, 182 U.S. at 287 (White, J., concurring).

55. See, e.g., United States v. Wong Kim Ark, 169 U.S. 649 (1898).

56. See supra note 3.

57. See, e.g., SPARROW, supra note 11, at 40-55; Cabranes, supra note 11, at 455-58; Erman, Reconstruction and Empire, supra note 29, at 11. Observing the continuing power of U.S. citizenship as a basis for claiming rights and status, this study also contributes to a new chronology of the legal rollback of Reconstruction. In doing so, it builds on work suggesting that legal fights over legacies of the Civil War - including the ability of former slaves and their descendants to access rights - stretched into the twentieth century, at which point they intertwined with fights concerning the constitutionality of empire. On twentieth-century legal fights over the legacy of Reconstruction, see BRANDWEIN, supra note 3 , at 1-7, 10, 18, 186-92, 238; supra note 51.

58. See, e.g., SPARROW, supra note 11, at 40-55; Cabranes, supra note 11, at 455-58; Erman, Reconstruction and Empire, supra note 29, at 11.

59. HENRY K. CARROLL, REPORT ON THE ISLAND OF PORTO RiCO 63 (1899).

60. Judge Magoon's Memorandum, WASH. Post, Apr. 12, 1900, at 4 (quoting Charles E. Magoon's written May 1899 opinion).

61. JESSUP, supra note 36, at 222 passim; Letter from John Griggs, Att'y Gen. to Elihu Root, Sec'y of War (Aug. 10 1899), MD NARA 350/8/12/C-182-70. 
tuition [for islanders] under a strong and guiding hand." ${ }^{62}$ Islanders, Root proposed, should have no say in who governed them, with the possible exception of being allowed to elect a lower legislative chamber. ${ }^{63}$ In preparing to promote these positions and establish his Department as an authority on colonial governance, Root drafted a long, internal legal memorandum in support. ${ }^{64}$

Magoon then revised his legal opinion, which was soon given wide distribution, in line with Root's views. ${ }^{65}$ Reviewing the treaties and statutes through which the United States had acquired and governed prior acquisitions, Magoon argued that eventual statehood and full constitutional rights for U.S. territories were matters of political grace, not constitutional requirements. ${ }^{66}$ Residents of the new acquisitions would be entitled to certain fundamental rights, Magoon conceded, though not jury trials. ${ }^{67}$ Further, they would not be entitled to enter the United States, in Magoon's view, until the political branches made their places of residence part of the United States. ${ }^{68}$

Magoon deemed U.S. citizenship too substantive to be universal among U.S. peoples. Because U.S. citizenship "carries with it great powers, rights, privileges, and immunities," he wrote, "the Government exercises its discretion in bestowing it." ${ }^{99}$ In addition to citizens, he added, are others "who owe[] allegiance to our Government." 70 Such allegiance could be a temporary status, like the "temporary allegiance" owed by "the alien domiciled in the country... during such residence." 71 And it could "be an absolute and permanent obligation" that falls between citizenship and alienage. ${ }^{72}$ Thus, he elaborated:

There are many persons within the jurisdiction of the United States from whom allegiance in some form is due who are not citizens of the United States. Many soldiers in our Army, sailors in our Navy, seamen in our merchant marine, travelers, temporary sojourners, Indians,

62. Elihu Root, The Military and Colonial Policy of the United States 165 (1916).

63. 1 ANNUAL REPORTS OF THE WAR DEPARTMENT FOR THE FISCAL YEAR ENDED JUNE 30, 1899. REPORT OF THE SECRETARY OF WAR. MisCELLANEOUS REPORTS, pt. 1, at 8-10 (1899); ROOT, supra note 62, at 161-68; [Elihu Root?], Untitled Internal Memorandum 2-36, 38-56, 61 (no date), MD NARA 350/5A/197/1444:9 (discussing potential constitutional limits on U.S. imperial governance).

64. [Root?], supra note 63.

65. Charles E. Magoon, Reports on the law of Civil Government in Territory SubJECT to Military OCCUPATION BY the MilitaRy ForCES OF THE UNITED STATES 81-120 (3d ed. 1903); infra notes 113-15.

66. MAGOON, supra note 65, at 81-110.

67. Id. at $110-14$.

68. Id. at 120 .

69. Id. at 119 .

70. Id. at 60-61, 114-15.

71. Id. at $114-15$.

72. Id. 
Chinese, convicted criminals, and, in another and limited sense, minors and women belong to this class. ${ }^{73}$

Because the Treaty of Paris that transferred Puerto Rico from Spain to the United States vested Congress with discretion over the status of the native inhabitants of Puerto Rico, Magoon indicated, Puerto Ricans owed absolute and permanent allegiance without yet being U.S. citizens. ${ }^{74}$

In 1900, the legal-political landscape again shifted, largely in line with Root's recommendations that Puerto Ricans receive limited rights, status, and self-government. ${ }^{75}$ Federal lawmakers enacted the Foraker Act, which in several ways protected nonjudicial federal officials' discretion in governing Puerto Rico and the ostensibly more racially degraded Philippines. ${ }^{76}$ While acknowledging the authority of the Court, lawmakers hoped to create in Puerto Rico a form of government that would mitigate the impact of judicial review. Designed with a judicial challenge in mind, the structure of the Foraker Act was such that an adverse judicial ruling on its provisions would not be directly applicable to the Philippines. Were the Court instead to issue a favorable ruling on the statute, lawmakers had structured the provisions of the Act to then be appropriate for rapid implementation via new legislation in the Philippines. ${ }^{77}$ To these ends, the political branches invited judicial review by imposing a modest tariff on U.S.-Puerto Rican trade in possible contravention of the constitutional bar on nonuniform tariffs for trade within the "United States.",78

As to whether Puerto Ricans enjoyed other constitutional rights, the Foraker Act was largely silent. The McKinley administration had initially sought, through its congressional allies, to secure U.S. citizenship for Puerto Ricans. But the administration had dropped the initiative in the face of concerns that doing so might accord Puerto Ricans too many rights or establish a precedent that the Supreme Court would hold applicable to Filipinos. ${ }^{79}$ Instead, the Act did not clarify the U.S. citizenship status of Puerto Ricans, whom it identified only as "citizens of Porto Rico." Nor did it indicate whether Puerto

73. Id. at 118 .

74. Id. at 118,120 passim.

75. CABÁN, supra note 13, at 89.

76. Foraker Act, Pub. L. No. 56-191, 31 Stat. 77 (1900); A Civil Government for Porto Rico: Hearings Before the Committee on Insular Affairs, House of Representatives, Sixty-Third Congress, Second Session, on H.R. 13818, A Bill to Provide a Civil Government for Porto Rico, and for Other Purposes, 63rd Cong. 53-54, 68-70 (1914) [hereinafter 1914 HouSE HEARINGS], MD NARA 350/5A/340/3377-157; Cabranes, supra note 13, at 414-15, 425, 429.

77. 33 Cong. Rec. 1946 (1900); Gerard N. MagliocCa, The Tragedy of William JENNINGS BRYAN 81-83, 108-14, 123, 143-45, 150-51 (2011) (discussing judicial supremacy as emerging and incomplete in the 1890s).

78. U.S. CONST. art. I, § 8, cl. 1; Foraker Act, Pub. L. No. 56-191, 31 Stat. 77, 77-79 (1900); 33 CONG. REC. 1946 (1900) (praising the Foraker bill for inviting judicial review) (cited in Krishanti Vignarajah, The Political Roots of Judicial Legitimacy: Explaining the Enduring Validity of the Insular Cases, 77 U. CHI. L. REV. 781, 822 \& n.177 (2010)); see also infra note 368.

79. 1914 HouSE HEARINGS, supra note 76, at 53-54, 68-70; Cabranes, supra note 13, at 414 $15,425,429$. 
Rico would become a state. ${ }^{80}$ And though the statute replaced War Department administration of Puerto Rico with a civil government, it extended the island little self-government, creating only an elected lower legislative chamber known as the House of Delegates and a Resident Commissioner to represent islanders in Washington. ${ }^{81}$ Elections were set for late $1900 .{ }^{82}$

Degetau quickly emerged as Republicanos' candidate for Resident Commissioner in an election campaign in which he shared with Federales a continued adherence to Spanish-era autonomist ideals of liberal republicanism and Puerto Rican self-government. ${ }^{83}$ To distinguish himself from his opposition, Degetau insisted that only he had done the "studies of . . American constitutional questions that underlay the issues of status" to "brandish" effectively "juridical meaning[s]" "in defense of the rights of our country." 84 He laid out a constitutional vision for Puerto Rico and the United States that was potentially also applicable to other new U.S. acquisitions, including the Philippines: ${ }^{85}$ Unlike in "monarchical and centralized nations" like Spain, where "patriotism... involve[d] a tension between love of region and submission to the family or city that personifies or stands in for the entirety of national life," $" 86$ the U.S. federal government did not dominate its regions. Instead, U.S. "patriotism ha[d] a double concept with profound love of native region acting as a basis and foundation for profound love and respect for the general state." 87 The answer to whether "there are in the United States ... or can be two classes of citizens, two conditions of rights," was that "basic principles of the Constitution of the United States" guaranteed Puerto Ricans "enjoyment of American citizenship" and Puerto Rico status as an "organized Territory now, in preparation to become an autonomous state of the union.," 88

80. Foraker Act, Pub. L. No. 56-191, 31 Stat. 77, 79, 83 passim (1900).

81. Id. at $82-84,86$.

82. BAYRON TORO, supra note 31 , at 115.

83. Un acuerdo, EL PAís, Sept. 20, 1900, CIHCAM 12/L2; La convención republicana, paper unknown, [early Oct. 1900?], CIHCAM 12/L2; see also, e.g., Spain Preferred to Our Neglect, DIARIO DE P.R., Feb. 24, 1900, CIHCAM 12/L2 (exemplifying Federales' continued support for liberal republicanism and Puerto Rican self-government).

84. Candidatos o candiditos, El DiARIO, Sept. 11, 1900, CIHCAM 22/L2 ("estudios sobre materia constitucional y determinadamente sobre las cuestiones constitucionales americanas de que depende el status"); F. Degetau y Gonzalez, A el “Diario," EL PAís, Sept. 15, 1900, CIHCAM 22/L1 ("una significación jurídica de cuya interpretación surgen armas que es preciso esgrimir, y que un día esgrimiré en defensa de los derechos de nuestro pais").

85. For more, beyond what appears below, on Degetau's treatment of the relationship of Puerto Rico to the Philippines, see, for example, Erman, supra note 15, at 60-65.

86. AsAmblea RePUBlicANA 29 (1899), CIHCAM 6/L2 ("el patriotismo en los pueblos monárquicos y centralizados supone un dilema entre el amor á la región y la sumisión á una familia ó á una ciudad, que encarnan y absorven [sic] la vida nacional toda").

87. Id. ("El patriotismo Americano tiene el doble concepto de amor profundo á la región nativa, como base y fundamento del amor y respeto profundos al Estado General.").

88. F. Degetau y Gonzalez, Puerto-Rico ante el Congreso, El PAís, Mar. 16, 1900, CIHCAM 18/L2 ("hay en los Estados Unidos ó que puede haber dos clases de ciudadanos; dos condiciones de derecho"); Candidatos o candiditos, supra note 84 ("principios básicos de la Constitución de los 
Any other result would effectively be saying, "Goodbye Washington, Goodbye Founding Fathers," because it would mean "that American citizenship had been reduced to the monopoly of 74 million oligarchs." $" 89$

U.S. officials also debated and moved to shape the future of U.S. empire in 1900. Those who administered Puerto Rico returned Republicanos' faith with favoritism. ${ }^{90}$ On the mainland, William Jennings Bryan, who advocated Filipino independence, accepted the Democratic presidential nomination with this anti-imperial jab at the Republican incumbent: the "forcible annexation of territory to be governed by arbitrary power differs as much from the acquisition of territory to be built up into States as a monarchy differs from a democracy... It is now proposed to ... force upon the [annexed] people a government for which there is no warrant in our Constitution." ${ }^{\text {91 }}$ As elections neared, Federales criticized U.S. officials' bias and boycotted the election. ${ }^{92}$ Now unopposed, Republicanos swept to power in Puerto Rico. ${ }^{93}$

Having ridden his attempted synthesis of U.S. and island constitutional ideals to island electoral victory, now-Resident Commissioner Degetau turned his efforts to convincing U.S. officials to embrace his vision. Degetau received another boost when his party's favored presidential candidate, William McKinley, won reelection. For mainland anti-imperialists who recognized that electoral politics were but one relevant lever of state power, McKinley's victory was an occasion to shift their eyes from the polls to the courts. ${ }^{94}$ Degetau similarly hurried to the mainland to hear arguments in the series of tariff and fee disputes concerning law and empire that came to be known as the Insular Cases. ${ }^{95}$

Estados Unidos"; "plenitud de la ciudadanía americana"; "Territorio organizado ahora, que se prepara para ser uno de tantos Estados Autónomos de la Unión").

89. Degetau, supra note 88 ("adios Washington, adios Padres venerables de la Constitución"); F. Degetau y Gonzalez, El Dilema, EL PAís, Mar. 20, 1900, CIHCAM 18/L2 ("con el ingreso de Puerto Rico en la Unión como 'Dependencia', la ciudadanía americana se redujo al monopolio de 74 millones de oligarcas").

90. CABÁN, supra note 13, at 167-68.

91. Fred H. Harrington, The Anti-Imperialist Movement in the United States, 1898-1900, 22 Miss. VAlley Hist. Rev. 211, 225-26 (1935); Mr. Bryan's Speech of Acceptance, N.Y. Times, Aug. 9, 1900, at 8; Democratic Party Platform of 1900, AM. PRESIDENCY PROJECT, http://www.presidency .ucsb.edu/ws/index.php?pid=29587\#axzz1mZkkpGXA (last visited June 21, 2014).

92. CABÁN, supra note 13, at 168 .

93. BAYRON TORO, supra note 31 , at 115-16.

94. On judges facing situations where political pressures that point in multiple directions leave them free to choose among a range of options, see, for example, Keck, supra note 7, at 517-18; Vignarajah, supra note 78; sources cited infra note 96; infra notes 319-20, 349-50.

95. Porto Rican Delegate, InDIANAPOLIS J., Dec. 3, 1900, CIHCAM 12/L2; American Life Split into Parts, PHILA. BULL., Dec. 19, 1900, CIHCAM 22/L2. 
II.

\section{AMBiguOUS DEClaRATIONS: THE INSULAR CASES OF 1901}

As Degetau settled into Washington in early 1901, the Supreme Court appeared poised to reshape the juridical landscape of U.S. empire. ${ }^{96}$ Two of the pending Insular Cases, DeLima v. Bidwell ${ }^{97}$ and Downes v. Bidwell, ${ }^{98}$ respectively turned on whether Puerto Rico was "foreign," hence subject to pre1900 tariff laws, or a part of the "United States" within which the Constitution demanded tariff uniformity (notwithstanding the ostensibly contrary dictates of the Foraker Act). These issues, in turn, raised the question of citizenship. As Frederic Coudert, the prominent international-law lawyer chosen to speak for private litigants in all seven Insular Cases, argued, "[I]f the inhabitants of these islands are citizens of the United States, it would be admitted that the islands themselves were part of the United States." Cases only involved Puerto Rican status and rights, presenting the Court with an opportunity to treat Puerto Rico and the Philippines differently. ${ }^{100}$

Degetau took a roseate view of his odds. He was optimistic that the Justices would unilaterally and decisively vindicate his constitutional view (and his campaign promise). ${ }^{101}$ But by simultaneously authorizing civil governance

96. The Insular Cases marked a transformation of political debates over U.S. imperialism into judicial ones. See, e.g., SPARROW, supra note 11; Torruella, supra note 48, at 284-85; Vignarajah, supra note 78. For similar contemporary observations, see, for example, Federico Degetau, Manifiesto del Comisionado Señor Degetau, LA CORRESPONDENCIA, June 6, 1901, CIHCAM 12/L2 (describing how both Democrats and Republicans viewed the cases as deciding partisan issues). The transformation was possible because political challenges to U.S. imperialism failed, see, e.g., supra notes 13, 21; discussion and external sources cited infra note 119; DUNNE, supra note 5, at 26 (perceiving an influential Republican victory at the national level in 1900 that, in conjunction with the prior citations, reveal that with Republicans firmly in control of the political branches, Democrats' first realistic opportunity to end imperialism would not come until more than half a decade after its implementation, by which point the bell might prove unringable); cf., e.g., text accompanying, discussion within, and external sources cited infra notes 311-12, 325-32 (observing that by 1914 leading Democrats had come to see advantages in perpetuating U.S. empire), because many mainlanders framed objections to U.S. empire in constitutional terms, see, e.g., Torruella, supra note 48, at 290, 296-98; Vignarajah, supra note 78, at 826-31; Democratic Party Platform, supra note 91; cf. Susan S. Silbey, After Legal Consciousness, 1 ANN. REV. L. \& SOC. SCI. 323 (2005) (reviewing and extending work on legal consciousness); Silverstein, supra note 16, at 1080 (calling attention to how legal language, legal ideas, and legal reasoning structure political debates and policy choices even absent explicit judicial intervention); Graber, supra note 17 (on the autonomy of law more broadly), because the political branches deliberately encouraged judicial intervention, see, e.g., Cabranes, supra note 13, at 423, 435; Erman, supra note 15, at 38; Vignarajah supra note 78, at 820-23, and becauseas will become clear-federal administrators declined to provide answers to some of these questions, see, e.g., infra Part III.

97. De Lima v. Bidwell, 182 U.S. 1 (1901).

98. Downes v. Bidwell, 182 U.S. 244 (1901).

99. Transcript of Opening Argument of Mr. Coudert for Plaintiff in Error at 9, Downes v. Bidwell, 182 U.S. 244 (1901) (No. 507) [hereinafter Coudert's Downes Argument].

100. See, e.g., SPARROW, supra note 11, at 122-23.

101. See, e.g., Erman, supra note 15, at 90; Untitled article, DET. NEWS, Dec. 3, 1900, CIHCAM 12/L2; Draft Letter from Federico Degetau to Manuel Rossy (Feb. 20, 1901), CIHCAM 2/VII/47. Many scholars now view the early Insular Cases as instances of the kind of rapid, unilateral 
in Puerto Rico, generally declining to clarify Puerto Rican rights and status, and imposing a modest tariff on island-mainland trade, the authors of the Foraker Act had reduced the likelihood and potential impact of a ruling against the government in Downes. The tariff provision of the Foraker Act, which did not directly involve the Philippines, U.S. citizenship, or the Bill of Rights, presented a potentially narrow issue. Moreover, civil government under the Act now existed in Puerto Rico and groundwork was being laid for a similar approach in the Philippines. Upholding the law would mean avoiding disruptions to already-underway imperial governance. And even if the Court ruled against the government, there was no guarantee that it would do so on grounds favored by Degetau. The Justices could also strike down the Foraker Act tariff without seriously constraining the discretion of the political branches to administer U.S. empire and determine the status and rights of recently acquired people and places.

In May, the Court issued its decisions. The Justices upheld some but not all of the challenged tariffs. DeLima overturned the imposition of pre-1900 tariffs on U.S.-Puerto Rican shipments. Writing for the Court, Justice Henry Brown concluded that Puerto Rico "was not a foreign country within the meaning of the tariff laws" enacted prior to $1900 .{ }^{102}$ Downes upheld the imposition of an explicit tariff on mainland-island commerce. Brown announced that judgment as well, opining that Puerto Rico was "not a part of the United States within the revenue clauses of the Constitution," and so outside their prescription of tariff nondiscrimination "throughout the United States." 103 According to Brown, Congress had chosen not to treat Puerto Rico as a foreign country before 1900 even though the Constitution would have permitted it to do so.

As Degetau observed, "The decisions ... produced a perplexity."104 The Court seemingly included Puerto Rico within the nation for one statutory purpose (deeming it non-foreign), but not for a different constitutional one. In Downes, held by contemporary observers and their successors to be the most important Insular Case, ${ }^{105}$ no opinion garnered five votes. And in both cases, four justices dissented. It clarified matters little that the Court soon declared Downes and DeLima applicable to the Philippines. ${ }^{106}$

judicial change to the constitutional order that Degetau envisioned. See, e.g., supra notes 21 and 23; infra text accompanying note 348; infra notes 335, 347, 356-65 and accompanying text. As we will see, they were not.

102. De Lima, 182 U.S. at 200.

103. Downes, 182 U.S. at 287; U.S. ConST. art. I, § 8, cl. 1.

104. Degetau, supra note 96 ("Las decisiones del Tribunal Supremo de los Estados Unidos ... han producido una perplejidad”); Charles E. Littlefield, The Insular Cases, 1 S.L. REV. 477, 478 (1901).

105. See SPARROW, supra note 11, at 80; Erman, supra note 15, at 6-7.

106. See, e.g., SPARROW, supra note 11, at 125-26. 
The most notable of the opinions was Justice Edward Douglas White's Downes concurrence, which proposed a new territorial nonincorporation doctrine. ${ }^{107} \mathrm{He}$ asserted that Puerto Rico, unlike prior territories, had not been incorporated by statute or treaty into the Union. U.S. citizenship figured prominently in the analysis. White juxtaposed the frequency with which the federal political branches had expressly extended the status to previously acquired peoples with the absence of any similar clause in the Foraker Act. ${ }^{108}$ He concluded that the Constitution applied differently in Puerto Rico than in prior territories, providing few details beyond generally announcing that Puerto Rico was "foreign to the United States in a domestic sense" while also U.S. land under international law. ${ }^{109}$

As to citizenship, White imagined:

Citizens of the United States discover an unknown island, peopled with an uncivilized race, yet rich in soil. Can it be denied that such right [to acquire] could not be practically exercised if the result would be to endow the inhabitants with citizenship of the United States .... ${ }^{110}$

Presuming U.S. citizenship to be too consequential for some colonized peoples, he concluded that constitutional marriage of annexation to naturalization would leave the United States "helpless in the family of nations." "111

Although many classed Puerto Ricans as a relatively civilized people, Justice Brown was more concerned with using his opinion to guard the mainland against purportedly savage Filipinos than with finding ways to distinguish Puerto Ricans. As he later told Coudert, the case had implications for the Philippines, where "he was much preoccupied by the danger of racial and social questions" and so was "quite [] desirous ... that Congress should have a very free hand."

Charles Magoon, the law officer for the Bureau of Insular Affairs within the War Department, saw affirmation in the decision and the events preceding it: His legal analysis won the approval of the Secretary of War and highranking officials in other departments and was sanctioned by the political branches through the Foraker Act. ${ }^{113}$ The U.S. public had then shown its support by giving Republican proponents of the Act electoral victories. ${ }^{114}$ Now, the Supreme Court had "sustained" his analysis as well. ${ }^{115}$

107. Downes, 182 U.S. at 287 (White, J., concurring).

108. Id. at 320-36, 340-41 (White, J., concurring).

109. Id. at 341 (White, J., concurring).

110. Id. at 306 (White, J., concurring).

111. Id.

112. See Frederic R. Coudert, The Evolution of the Doctrine of Territorial Incorporation, 26 ColuM. L. REV. 823, 832 (1926).

113. MAGOON, supra note 65 , at 120.

114. Id.

115. Id. 
Degetau also saw affirmation in the decisions. He had hoped that the Court would hold the Uniformity Clause applicable to Puerto Rico, thereby prohibiting any tariff on mainland-island trade, and he disagreed with Justice White concerning citizenship. Nonetheless, Degetau interpreted the outcomes as consistent with his campaign to win official recognition of Puerto Ricans as U.S.-citizen residents of a U.S. territory. The day after the decision came down, Degetau met Justice Brown, tested his new ideas before the Justice, and reported himself "very much pleased" with the decisions. ${ }^{116}$ The position that the Justices occupied, he told his island audience, had allowed them to issue a "high and serene solution" to the politically contentious cases. ${ }^{117}$ Stressing the Justices' "practical unanimity that Porto Rico is 'a territory of the United States," he contended that detached observation revealed that Puerto Rico was no more "a 'possession' or ... 'colony" under the recent Insular Cases than was "Arizona." 118

The truth lay between Magoon's and Degetau's positions. Magoon was right that his legal analysis for the War Department had found support with administrators and elected officials and to lesser degrees with the public and the Justices. But the Court had not declared Magoon's views to be binding doctrine. And while the Court had not foreclosed Degetau's arguments, few agreed that the cases guaranteed Puerto Rico the same status as Arizona. Rather, the cases raised without ruling upon the possibility of unincorporated U.S. territory, territory that was neither foreign nor domestic. That ambiguous legal innovation left open many questions about the relationship between the Constitution and imperialism. As U.S. governance of new imperial acquisitions continued to reshape the official landscape, nonjudicial officials and those who brought claims before them would discover opportunities to help provide answers. ${ }^{119}$

116. As Degetau Sees It, BALT. Sun, May 28, 1901, CIHCAM 18/L1; Draft, Letter from Federico Degetau to Querido Besosa (May 31, 1901), CIHCAM 3/I/43.

117. Degetau, supra note 96 ("alta y serena solución").

118. Federico Degetau, Letter to the Editor, Porto Rico, Territory, BufFalo COURIER, July 31, 1901, CIHCAM 18/L1; Degetau, supra note 96 ("una <posesión> ó ... una <colonia>"; "Arizona").

119. Although these cases have been of great interest to scholars studying the relationship between politics and law, a comprehensive account of their role in dynamics throughout the U.S. state remains elusive. Krishanti Vignarajah takes important preliminary steps. On her telling, after the national political branches failed to resolve debates over U.S. imperialism through normal political challenges, they invited the Court to adjudicate the dispute, which the Court resolved in the Insular Cases of 1901. See Vignarajah, supra note 78. While she likely overstates both political irresolution of questions of empire, see L. David Roper, Composition of Congress Since 1867, http://arts.bev.net/ roperldavid/politics/congress.htm (last visited June 21, 2014) and Historical Election Results: 17892012 Presidential Elections, NATIONAL ARCHIVES AND RECORDS ADMINISTRATION, http://www.archives.gov/federal-register/electoral-college/votes/index.html (last visited June 21, 2014) (together revealing that Republicans, who were associated with imperialism, increased their margins of victory in presidential and congressional campaigns after the issue arose and that Republicans controlled both political branches from 1897 to 1911), and the extent to which the Court's 1901 decision settled such questions, see infra Part V; infra text accompanying note 348; infra notes 335, 
III. DegetAu SEeKs CitizenshiP Without Filing Suit, 1901-1902

Degetau spent the balance of his first term seeking U.S. citizenship for Puerto Ricans as a purported proof and consequence of their meriting full belonging within the U.S. nation. ${ }^{120} \mathrm{He}$ worked to build relationships with mainland audiences and exemplified before them the readiness for integration into U.S. life that he attributed to Puerto Ricans. He quickly won a reputation as a "highly... diplomatic man" of "brilliant attainments" who "created a favorable impression in the public life of Washington." "And soon Degetau was making near-daily visits to the Capitol, attending meetings with executive and judicial officials, and gaining entry to newspapers and academic gatherings. $^{122}$

But access and regard did not translate into results. "[C]ongressmen don't plan to turn to Puerto Rican matters," he discovered, because the Supreme Court still might offer further, potentially constraining guidance. ${ }^{123}$ As Henry Cooper (the lawyer-Chairman of the House Committee on Insular Affairs and Degetau's friend) relayed, many congressmen also believed that "Puerto Rico can't be considered in itself" because the "Philippines also has to be taken into

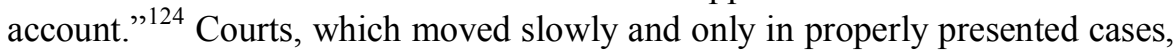
also promised no immediate relief. Racial bias further impeded Degetau's campaign. Once on the mainland, Degetau saw that public opinion often ignored the accomplishments of leading Puerto Ricans and cast typical islanders as a racially inferior, dependent people akin to Filipinos and of

347, 356-365 and accompanying text, her observation that political actors sought limited judicial review opens the door to work on the possibility of a "dynamic dialogue between the courts and representatives of the people" with the potential to "validate[] and strengthen[] the actions of each," Vignarajah, supra, at 787; see also infra text accompanying, discussion within, and external sources in note 371. Bartholomew Sparrow's account of the Insular Cases, see SPARROw, supra note 11, which combines careful overview of the decisions with attention to the institutional nature of the Supreme Court, provides crucial foundation for the envisioned project. Scholars drawing on Regime Theory have also seen confirmation of their view that politics largely drives law in the Insular Cases. See, e.g., Keck, supra note 7, at 531 (quoting JefFrey Rosen, THE MOST DEMOCRATIC BRANCH, at xii (2006), as endorsing "Finley Peter Dunne's famous cartoon aphorism" concerning the Insular Cases: "Mr. Dooley was correct when he declared at the turn of the last century that "th' supreme coort follows th' illiction returns"'”'); see also supra notes 33-34.

120. Barbara Young Welke, LaW and the Borders of Belonging in the Long NINETEENTH CENTURY UNITED STATES (2010).

121. A Credit to Porto Rico, WASH. TIMES, Nov. 9, 1901, CIHCAM 18/L1; Hawaii and Porto Rico at Washington, ST. PAUL PIONEER PRESS, Feb. 10, 1901, CIHCAM 12/L2.

122. See Erman, supra note 15, at 110 \& n.132; see also, e.g., Federico Degetau, The Porto Ricans as Soldiers and as Legislators, PHILA. REC., May 23, 1901, CIHCAM 12/L2.

123. Diary Entry of Federico Degetau (Jan. 8, 1902), CIHCAM 11/L4 ("los congressmen no piensan ocuparse de PR"). On congressional unwillingness to act while the 1901 Insular Cases pended, see, for example, Draft Letter from Federico Degetau to Manuel Rossy (Jan. 18, 1901), CIHCAM 2/VI/11.

124. Diary Entry of Federico Degetau (Dec. 10, 1901), CIHCAM 11/L4 ("no se puede considerar á Puerto Rico en sí, sino que hay que tener en cuenta á Filipinas"). 
African, native, and southern-European heritages. ${ }^{125}$ This, he told allies, "ma[de] our political labor here hard."126

Degetau responded by turning to available levers of power. In settling so little about the relationship between the U.S. Constitution and imperialism, the Insular Cases had made room for institutions other than courts to maneuver. ${ }^{127}$ Seizing upon this new space, Degetau placed claims to U.S. citizenship before officials from across the federal government. He especially targeted administrators, whom he perceived played potential roles in establishing constitutional meaning. ${ }^{128}$ Degetau also chose this route because as a member of a professional class, a representative of workers facing a dearth of jobs, and an official elected by the patronage-based political system in Puerto Rico, his primary concerns included equality of access to employment and professional opportunities for Puerto Ricans. In these matters, administrative authorities often acted as initial, rule-bound decision makers - and sometimes as the final ones. ${ }^{129}$ Their commitment to deciding properly presented live controversies created opportunities that Degetau took up to seek clarification of islanders' constitutional status. ${ }^{130}$

To bolster his efforts, Degetau crafted arguments for U.S. officials and the broader U.S. public. He insisted that Puerto Ricans merited full membership within the Union because their leading men shared with their mainland counterparts European heritage, markers of civilization such as paternal concern for ostensible racial inferiors and political experience, and longstanding, effective commitments to liberal-democratic ideals.

Degetau thus met the new circumstances that accompanied U.S. rule by seeking U.S. citizenship for Puerto Ricans based on the common struggles of (implicitly white) leading men in both locales for liberal-republican ideals such

125. Porto Ricans' Ambition, WASH. TIMES, July 10, 1901, CIHCAM 18/L1; Diary Entry of Federico Degetau (Dec. 10, 1901), CIHCAM 11/L4.

126. Letter from Federico Degetau to Manuel Rossy et al. (Dec. 8, 1900), CIHCAM 2/V/12; Letter from Federico Degetau to Manuel Rossy (Jan. 4, 1901), CIHCAM 2/VI/2.

127. See supra note 17.

128. See supra note 9.

129. Although not the focus of this paper, the outsized role that federal administrators played in Puerto Rican governance suggests that U.S. imperialism provided administrators opportunities to increase the bureaucratic capacity of their organizations. See, e.g., CABÁN, supra note 13, at 2, 8, 16, 43, 45, 49, 118-19, 174-75, 189 (focusing on growth of U.S. colonial government); CARPENTER, supra note 9 (describing how bureaus and divisions could accrue power through developing unique expertise valued by networks with whom they interacted); THEDA SKOCPOL, PROTECTING SOLDIERS AND MOTHERS (1992) (describing how new policies can transform capacities of certain institutions within the state which, in turn, play roles in establishing policy). On administrative law, see, for example, Mashaw, supra note 7.

130. See Lee, supra note 10, at $806 \mathrm{nn} .14-16$ (collecting sources describing how agencies often work on matters of potential constitutional moment and how they and reviewing courts should proceed in such cases). 
as individual rights, democracy, and emancipation. ${ }^{131}$ Instead of attacking racial hierarchy, he moved to secure Puerto Ricans what he perceived to be their rightful place in it. Mixing arguments favoring U.S. citizenship specifically for Puerto Ricans and more generally for all U.S. people, he proposed to solve nested puzzles concerning island and mainland constitutionalism. The U.S. Constitution, he told island voters and U.S. officials, both secured Puerto Ricans the liberation they had long sought and accounted for U.S. empire by making islanders U.S. citizens of a traditional U.S. territory destined for statehood and concomitant self-government. The promise of this strategy marked out its perils. U.S. officials would either both embrace Degetau's robust constitutional vision and accept Puerto Rican political leaders as racial peers or reject a crucial premise of Degetau's argument. $^{132}$

Degetau soon discovered that federal administrators often moved tentatively, sidestepping definitive resolution of constitutional questions involving status and empire where possible. He, in turn, sought individual island claimants whose disputes could only be resolved through clarification of their status or that of their homeland. ${ }^{133} \mathrm{He}$ knew that each time an administrative body treated Puerto Ricans as U.S. citizens or Puerto Rico as a traditional U.S. territory, it created a potentially persuasive precedent and neutralized arguments that those statuses were incompatible with imperial governance. $^{134}$

Degetau launched one claim by drawing on his recent acquaintance with legally trained Acting Secretary of State David Hill. In January 1901, Degetau suggested that Hill could prevent "trouble for the agents of the Government, and for Porto Ricans" by stating when "Puerto Ricans are to be considered as aliens, according to the immigration law, and when they are to be allowed to land as citizens of the United States." 135 For the moment, Degetau suggested,

131. On lawyers and the bar as a potentially powerful institution within the U.S. state, see PAUl Frymer, Black AND Blue 6-7, 15-16, 70-90, (2008); Daniel R. Ernst, The Politics of Administrative Law: New York's Anti-Bureaucracy Clause and the O'Brian-Wagner Campaign of 1938, 27 LAW \& Hist. REV. 331 (2009); Daniel R. Ernst, Morgan and the New Dealers, 20 J. POL'Y HiST. 447, 449 passim (2008); Novak, supra note 9, at 767; John D. Skrentny, Law and the American State, 32 ANN. REV. OF SOC. 213, 231 (2006); Whittington, supra note 7, at 618; Witt, supra note 15, at 769-70 (noting that four of the most important secretaries of war were lawyers).

132. On certain other island leaders' attempts to navigate the crosscurrents of U.S. liberaldemocratic ideals and of white mainstream thought concerning race on the mainland, see Erman, Reconstruction and Empire, supra note 29.

133. Cf. Mashaw, supra note 7 (arguing that administrators were, by this period, already engaging in mass adjudications according to administrative law that they helped to create).

134. Cf. Jerry L. Mashaw, Between Facts and Norms: Agency Statutory Interpretation as an Autonomous Enterprise, 55 U. TORONTO L.J. 497, 515-16 (2005) (observing that agencies more than courts are the institutions to push constitutional limits and be able to shape constitutional settlements by lobbying, testing waters, negotiating, and reaching accommodations).

135. Las gestiones de Degetau en defensa de los emigrantes á las islas Hawaii, LA CORRESPONDENCIA, Sep. 25, 1901, CIHCAM 12/L2 [hereinafter Las Gestiones De Degetau]; Letter 
U.S. immigration policy toward Puerto Ricans was inconsistent. Beginning in 1900, Hawai'ian sugar planters facing tightening labor supply due to Chinese Exclusion had begun to recruit and bring over 5,000 financially distressed Puerto Rican laborers to their plantations via New Orleans. ${ }^{136}$ While these migrants faced no immigration inspections, Degetau told Hill, on November 24, 1900, "Mr. Alfonso Gómez y Stanley, a professor who had acted as U. S. Interpreter at the Paris Exposition,... was [temporarily] detained at Ellis Island, N. Y., when it was known that he was a Porto Rican, and that he had no money." 137 Hill's response was encouraging: "the error of holding [Gómez], even temporarily, evidently arose from the lack of knowledge of some [immigration] officer as to the status of Porto Ricans." 138 Degetau then sought further clarification, observing that "[c]oncerning the Administration's opinion of the status of Porto Ricans nothing was said." ${ }^{139}$ But with no pending claim hinging on the answer, which had the potential to limit federal control over migration from newly U.S. lands to the states of the Union, the State Department silently declined the invitation to specify further what exactly Puerto Ricans were.

Degetau also launched a claim with Hill based on newspaper reports of official restrictions on the freedom of movement of other Puerto Ricans en route to Hawai'ian plantations. In Texas, he told Hill, islanders had been "arrested as violators," ostensibly, "of the criminal law." 140 Later, police had restored and maintained order on a steamship in Honolulu Harbor that was transporting migrants to their work sites. ${ }^{141}$ Apparently believing that federal law barred police from arresting or subduing U.S. citizens for declining to travel to engage in contracted-for labor, Degetau told the island press that the charges suggested that "Puerto Ricans lacked all political protections, and did not know what type of citizens they were." ${ }^{, 42}$ Hill ordered an investigation, and Hawai'ian officials and planters, who hoped to continue recruiting Puerto Rican laborers, used the investigation to exculpate themselves and laud migration. ${ }^{143}$ Their report trumpeted that migrants were "all satisfied with the

from Federico Degetau to the Secretary of State (Jan. 31, 1901), CIHCAM 2/VII/65; see also AUBREY PARKMAN, DAVID JAYNE HILl AND THE PROBLEM OF WORLd PEACE 65-71 (1975) (discussing Hill's position as Acting Secretary of State and legal training).

136. For sources, see Erman, supra note 15, at 89 n.103.

137. Letter from Federico Degetau to the Secretary of State, supra note 135.

138. Letter from David Hill to Federico Degetau (Feb. 16, 1901), CIHCAM 2/VII/4.

139. Federico Degetau y González, Memorandum in Relation to the American Citizenship of Porto Ricans (undated), CIHCAM 2/VI/19-A; [Federico Degetau] to Secretary of State, Feb. 15, 1901, CIHCAM 2/VII/39.

140. Draft Letter from Federico Degetau to the Secretary of State (Jan. 31, 1901), CIHCAM 2/VI/19.

141. Id.

142. Las gestiones de Degetau, supra note 135 ("los puertorriqueños carecían de toda protección política, y no se sabía siquiera qué clase de ciudadanos eran”).

143. Id.; Letter from Federico Degetau to the Secretary of State, supra note 140; Letter from David Hill to Federico Degetau (Feb. 16, 1901), CIHCAM 2/VII/40. 
treatment they received in transit." ${ }^{144}$ Had Degetau wanted to question the report, he could have noted that all statements in it were made by or before planters and their allies. ${ }^{145}$ But Degetau was no radical on labor questions. He ultimately sought to be treated as the equivalent of Hawai'ian officials, as a white U.S. leader of a U.S. territory. He did not wish to have his fate determined by association with Puerto Rican workers. With no further progress on issues of status immediately possible, Degetau celebrated that the charges "were not true."146

Next, Degetau tried to win recognition of his (and by extension all Puerto Ricans') U.S. citizenship by gaining admission to the U.S. Supreme Court Bar. He applied, well aware that "the court permits only citizens of the United States to practice before it." ${ }^{\prime 47}$ The Court, acting summarily, admitted him. ${ }^{148}$ Interpreting this victory broadly, he announced, "My admission . . fixed my personal Status and that of my constituents as American citizens."149 Sympathetic island newspaper articles added that now "The Great National Constitution Covers Puerto Rico," which had come to hold the same status as "other territories like Arizona." ${ }^{150}$ Many mainland newspapers and lawyers also saw Degetau's admission as a positive signal from the Court concerning the place of Puerto Ricans in the U.S. legal order. ${ }^{151}$

After gaining admission, Degetau published a defense of Puerto Rican civilization and capacity in the Philadelphia Record and then circulated the article to a variety of U.S. officials. ${ }^{152}$ There and elsewhere he portrayed the island political class as committed, effective advocates for liberties and as experienced in self-government. Drawing on Spanish-era battles over both territorial status within the Spanish empire and the political status of Puerto Rico-born Spaniards, Degetau provided this stylized account of past events: ${ }^{153}$ In classical times, Latin ancestors of Puerto Ricans formulated principles upon

144. Letter from F. A. Schaefer to Sanford B. Dole (Mar. 6, 1901), CIHCAM 2/IX/3.

145. See generally items in the folder at CICHAM 2/IX.

146. Letter from Federico Degetau to the Secretary of State (Apr. 15, 1901), CIHCAM 2/IX/13.

147. Admission of Mr. Degetau, WASH. Post, May 1, 1901, CIHCAM 12/L2; Grata noticia, EL PAís, Apr. 30, 1901, CIHCAM 12/L2.

148. See supra note 147.

149. Draft Letter from Federico Degetau to Manuel Rossy (May 3, 1901), CIHCAM 3/I/4 ("Mi admisión ... queda pues mi Status definido y demostrado que somos los puertoriqueños ciudadanos americanos.").

150. Un Puertorriqueño, Importante comunicación, paper unknown, May 10, 1901, CIHCAM 12/L2 ("La Grán Constitución Nacional cubre á Puerto-Rico"; "otros Territorios como Arizona”).

151. See, e.g., Constitution Follows the Flag, MinN. TriB., May 1, 1901, CIHCAM 12/L2.

152. See, e.g., Degetau, supra note 122.; Letter from Theodore Roosevelt to Federico Degetau (June 24, 1901), CIHCAM 3/II/22; Letter from Henry Cooper to Federico Degetau (July 8, 1901), CIHCAM $3 / \mathrm{II} / 33$.

153. For less heroic accounts of historical Puerto Rican status and rights, see, for example, José Trías Monge, 1 Historia constitucional de Puerto Rico (1980); Francisco A. SCARANO, PUERTO RICO (1993). 
which U.S.-citizens-to-be later drew in formulating their Constitution. ${ }^{154}$ Spain joined the circum-Atlantic struggle for liberty soon afterward with its "noble and glorious" 1812 Constitution that Puerto Ricans played a key role in creating. ${ }^{155}$ Islanders' subsequent struggles helped create a Puerto Rico that was "a province of Spain equal to the other provinces," enjoyed more autonomy than U.S. states, sent representatives and senators to the Spanish Cortes, had "practically ... universal" male suffrage, and housed a population included in the Spanish Constitution with an identical juridical status to that of other Spaniards. ${ }^{156}$ In 1873, island liberals' efforts ended slavery in Puerto Rico. ${ }^{157}$

At the same time, Degetau sought to distance Puerto Ricans from blacks, American Indians, and indigenous Pacific islanders - in part by reinforcing the unenviable stations of those groups in U.S. racial hierarchies. In an account of slavery that rendered invisible the experiences of island slaves, Degetau insisted that "the whites were more enslaved by our mo[]nstrous crime than our legal victims." 158 Mainlanders, he elsewhere asserted at others' expense, were wrong to have the "idea that Porto Rico... was peopled by" "some race of semi-savage 'Indians." "159 He also purported to distinguish Puerto Ricans from residents of Guam, whom he deprecated as ostensibly existing on "the boundaries of a savage condition." 160 Reinforcing this claim, he insisted that such differences had led Spain to establish a more liberal government in Puerto Rico than on the bulk of its Pacific islands. ${ }^{161}$

In the latter half of 1901, Degetau turned to claims concerning passports and civil-service quotas. Doing so, he hoped, would build on his Supreme Court bar admission and recent public relations efforts to win express official

154. See American Life Split into Parts, supra note 95 (describing Puerto Ricans as among the "Latin peoples," asserting their "civilization," and telling mainlanders that "your Constitution is not exclusively an American product[, for t] he government would not exist had it not been for the principles formulated by Aristotle").

155. Degetau, supra note 122.

156. Federico Degetau, The Political Status of Porto Rico 14 (1902); Jacob H. Hollander et al., Discussion, in 3 Publications AM. ECON. Ass'N (3d ser.) 342, 347-50 (1902); Degetau, supra note 122; La American Economic Association y el Comisionado Señor Degetau, LA CORRESPONDENCIA, Jan. 22, 1902, CIHCAM 18/L1.

157. Degetau, supra note 122; LuIS A. FigueroA, Sugar, Slavery, \& Freedom in NINETEENTH-CENTURY PUERTO RICO 79 (2005).

158. Federico Degetau, Something that the American People Must Know about Porto Rico, no date, CIHCAM 7/I/2. Two drafts of this chapter have been preserved. I draw from both. On the instrumentalism of Degetau's treatment of slavery, see Erman, Reconstruction and Empire, supra note 29, at 26 (describing how Degetau's account of slavery “[aimed] to align Puerto Ricans like himself with leading Republicans and their racial privilege" by "overlooking realities of slave experiences [and scrubbing] the voices and travails of those once held in bondage from [his] depiction").

159. DEGETAU, supra note 156, at 7.

160. Federico Degetau, Puerto-Rico and Its People (no date) (unpublished manuscript), CIHCAM 18/L2; Federico Degetau, The Truth about Porto Rico (no date) (unpublished manuscript), CIHCAM 18/L2

161. See supra note 160. 
confirmation that Puerto Ricans were U.S. citizens or that Puerto Rico was a traditional U.S. territory. Degetau first protested the State Department's "issu[]ing of a passport to me, in which my American citizenship has been omitted." 162 Because federal law prescribed that "[n]o passport shall be granted or issued to or verified for any other persons than citizens of the United States," Degetau expected a response expressly addressing islanders' citizenship status. ${ }^{163}$ When the State Department instead failed to respond, Degetau prepared to file suit. ${ }^{164}$ But that effort stalled after Degetau learned that federal courts were unlikely to intervene in a case involving what Degetau's lawyer termed "ordinary official duties,[ ] ]even when those duties require an interpretation of the law." 165

In the interim, Degetau integrated his pursuit of U.S. citizenship for Puerto Ricans with a lobbying effort designed to win Puerto Rico full access to the civil-service system, which was required to hire a minimum quota of residents from most states and territories, but not from Puerto Rico. ${ }^{166}$ In addition to marking their island as potentially inferior to traditional U.S. territories, the near-total exclusion of Puerto Ricans from the civil service was bad politics for Republicanos. It reenacted the prior Spanish practice (long opposed by island liberals) of hiring preferences for those born on the continent over the island born. ${ }^{167}$ The discrimination mattered all the more because the Puerto Rican political system, like that in the United States, depended heavily on patronage. ${ }^{168}$

Degetau personally lobbied top officials in Washington about Puerto Ricans' status. In November 1901, Degetau again met with Supreme Court Justice Henry Brown, now for a "conversation concerning the citizenship of Puerto Rico." 169 When Brown pointedly inquired whether "Puerto Ricans would like to return to Spain," Degetau responded that "the Puerto Ricans are and desire to be American, although they believe that they have not been done justice, they still have faith." 170 A meeting around the same time with nowPresident Theodore Roosevelt "to speak of the Civil Service Law and

162. Letter from Federico Degetau to Henry Cooper (July 15, 1901), CIHCAM 3/II/33.

163. Revised Statutes of the United States Passed at the First Session of the FORTY-THIRD CONGRESS 1873-'74, at 786 (2d ed. 1878) (Title 47, § 4076). On the history of U.S. passports, including limitation of them to U.S. citizens, see Jeffrey Kahn, The Extraordinary Mrs. Shipley: How the United States Controlled International Travel Before the Age of Terrorism, 43 CONN. L. REV. 819 (2011).

164. See Letter from Henry Webb to Federico Degetau (Aug. 10, 1901), CIHCAM 3/III/56 (correspondence from Degetau's lawyer discussing his research on his "case").

165. Letter from Henry Webb to Federico Degetau (Aug. 14, 1901), CIHCAM 3/II/61.

166. See Erman, supra note 15, at 105 n.125 (providing sources).

167. See supra note 27.

168. See supra note 27.

169. Diary Entry of Federico Degetau (Nov. 18, 1901), CIHCAM 11/L4 ("conversación acerca de la ciudadanía de Puerto Rico").

170. Id. ("si los puertoriqueños [sic] querian [sic] volver á España"; "Los puertoriqueños [sic] son y desean ser americanos, aunque creen que no se les ha hecho justicia, pero confian"). 
citizenship" culminated in that former Columbia Law School student requesting a written statement from Degetau. ${ }^{171}$ After a discussion with a "Com[missione]r of the Civil Service," Degetau reported that "Puerto Ricans get a quota." 172 A week later, Degetau had a "Conference with the Sec[retary] of State concerning the citizenship" of Puerto Ricans. ${ }^{173}$

In his missive to President Roosevelt, Degetau laid out legal arguments that favored recognition of Puerto Ricans as U.S. citizens - without necessarily requiring similar treatment of Filipinos. ${ }^{174}$ Implicitly equating nationality and citizenship, he wrote that the Treaty of Paris recognized some Puerto Ricans "as having accepted the nationality of the territory in which they resided"; that Puerto Rico, under the Insular Cases, was "a territory of the United States"; and that recent legislation lumping together "all inhabitants" of the island had made the balance of Puerto Ricans into U.S. citizens. ${ }^{175}$ Degetau reached the same result by noting legislation that constituted mainlanders and Puerto Ricans residing on the island into the "people of Porto Rico" and by presuming that such a "political body cannot be constituted with American citizens and other members of distinct nationality or distinct... citizenship." ${ }^{176}$ He then reminded Roosevelt that Puerto Ricans' embrace of U.S. troops had partly followed General Guy Henry's 1898 promise to islanders of "protection as citizens of the American Union." 177 "The only constitutional and just interpretation," he concluded, is that all "citizens of Puerto Rico" are "American citizens.", 178

In late 1901 and early 1902, Roosevelt and U.S. officials chose to avoid Degetau's claims rather than answer them. The legally trained Secretary of

171. Id. ("para hablarle de la ley del Civil Service y de la ciudadanía"); H.W. BRANDS, T.R.: THE LAST ROMANTIC 110 (1997). Roosevelt had ascended to the presidency in the wake of President McKinley's assassination several weeks prior. See Mr. Roosevelt Is Now the President, N.Y. TIMES, Sept. 15, 1901, at 1.

172. Diary Entry of Federico Degetau (Nov. 18, 1901), CIHCAM 11/L4 ("Comr del Civil Service"; "Conseguida quota los puertoriqueños [sic]"). Two of the three Civil Service Commissioners were lawyers. See Eighteenth Report of the United States Civil Service Commission 23 (1902); William Dudley Foulke, A Hoosier Autobiography 13-14 (1922); Biographical Directory of the United States Congress 1774 - Present, CONGRESS.GOV, http://bioguide.congress .gov/biosearch/biosearch.asp (last visited July 13, 2014).

173. Diary Entry of Federico Degetau (Nov. 25, 1901), CIHCAM 11/L4 (“Conferencia con el Sec de Estado acerca de la ciudadanía.").

174. Federico Degetau Gonzalez, newspaper unknown, no date, CIHCAM 18/L1/195 (quoting Federico Degetau to Theodore Roosevelt, Dec. 7, 1901). In 1902, Degetau's first two arguments became potentially applicable to the Philippines following enactment of the Philippine Bill of 1902, Pub. L. No. 235, 32 Stat. 691 (1902), which used similar language to that used in the Foraker Act.

175. Federico Degetau Gonzalez, supra note 174 ("habían aceptado la nacionalidad del territorio en que residían"; "un territorio de los Estados Unidos"; "todos los habitantes").

176. Id. ("pueblo de Puerto Rico"; "una entidad o cuerpo político no puede constituirse con ciudadanos americanos y otros miembros de distinta nacionalidad o distinta . . . ciudadanía").

177. Id. ("protección como ciudadanos de la Unión Americana").

178. Id. ("La única interpretación constitucional y justa de la ley es ... que las palabras ciudadanos de Puerto Rico es una designación de ciudadanía americana.”). 
State extended to Puerto Ricans abroad "the same "protection of person and property as is accorded to the native-born citizens of the United States." Then, with President Roosevelt's support, he sought and won legislation allowing the State Department to grant passports to U.S. insular residents regardless of U.S. citizenship. ${ }^{179}$ Rather than recognize islanders as U.S. citizens and thereby commit themselves to providing whatever rights followed, the Secretary and President sidestepped the question of U.S. citizenship by parceling out to Puerto Ricans individual incidents of the status.

Degetau's next pair of claims met similar mixes of evasion and halfmeasures by U.S. officials. In one, Degetau set out to manufacture a test case by importing paintings by a Puerto Rican artist and claiming a duty exemption for " $[\mathrm{w}]$ orks of art, the production of American artists residing temporarily abroad." " 180 On May 13, 1902, the Attorney General gave only modest ground in response. ${ }^{181}$ Puerto Rican artists were also "American artists," he wrote, before cautioning, "It is clearly not inconceivable for a man to be an American artist within the meaning of such a statute and yet," like an "American tribal Indian, or a native Alaskan," be "not a citizen of the United States.", 182

Around the same time, Degetau sought to have congressional allies shepherd a bill through Congress making him a delegate who, like those from traditional territories, could speak but not vote in the House. ${ }^{183}$ Appearing before the House Committee on Insular Affairs, Degetau addressed concerns that Puerto Rican legislation would become a precedent for the Philippines. He stressed that U.S. military authorities promised Puerto Ricans (but not Filipinos) U.S. citizenship and required from Puerto Rican (but not Filipino) officeholders naturalization-like oaths to uphold the U.S. Constitution, give allegiance to the United States, and renounce fidelity to foreign nations. ${ }^{184}$ Degetau's attempt to secure gains for Puerto Rico at the expense of the Philippines worked in part. The House Committee recommended the bill, only

179. Federico Degetau, A Letter from Mr. Degetau, P.R. HERALD, Jan. 11, 1902, at 4; H.R. 8129, in H.R. REP. NO. 57-559 (1902), CIHCAM 3/V/20; THEODORE ROOSEVELT, Rules GOVERNING THE GRANTING AND ISSUING OF PASSPORTS IN THE INSULAR POSSESSIONS OF THE United States (1902), MD NARA 350/5B/837/19929; Civil Service in Porto Rico, Wash. Post, Feb. 10, 1902, 4; see also Law of June 14, 1902, Pub. L. No. 158, 32 Stat. 386 (1902); see also 35 CONG. REC. 4992-95, 5697-99, 6588-89 (1902); HAY, JOHN, http://www.brown.edu/Administration/ News_Bureau/Databases/Encyclopedia/search.php?serial=H0060 (1993), reprinted from MARTHA MitCHELl, ENCYClOPEDIA BRUNONIANA (1993); Diary Entry of Federico Degetau (Nov. 25, 1901), CIHCAM 11/L4.

180. American Artist-Citizen of Porto Rico-Duties, 24 Op. Att'y Gen. 40, 41, 42-44 (1902) (giving as the source of the quotation "section 703 of the tariff act of July 24, 1897").

181. See id. at 40, 41-44.

182. Id. at 40-41; see also Porto Rican an American Artist, WASH. POST, May 17, 1902, at 11.

183. COMMITTEE REPORTS, HEARINGS, AND ACTS OF CONGRESS CORRESPONDING THERETO: COMMITTEE ON INSUlAR AFFAIRS (1903) [hereafter COMMITTEE ON INSUlAR AFFAIRS]; Letter from Federico Degetau to William Hunt (May 16, 1902), CIHCAM 3/VI/5.

184. COMMITTEE ON INSULAR AFFAIRS, supra note 183, at 35-37. 
to have the Senate strike from another bill the language that would have given Puerto Rico a voice in the House, thus dooming the effort for the term. ${ }^{185}$

By mid-1902, it was becoming clear that Degetau's plan was not paying expected dividends. In seeking clarification of the status of Puerto Rico and Puerto Ricans, Degetau had succeeded in finding numerous ways to place before U.S. officials disputes involving whether Puerto Ricans were U.S. citizens and whether Puerto Rico was a traditional U.S. territory. In each case, U.S. officials had responded with half-measures, evasion, and ambiguity. Administrators had not stepped into the doctrinal breach in the ways that Degetau had anticipated. To add insult to injury, his efforts to sway public and official opinion in favor of Puerto Rican racial capacity did little to stem what he perceived to be mainlanders' false criticisms of Puerto Rico, such as antiimperialist Bishop John Spalding's announcement in mid-1902 that in "the tropics the race is and, probably always will be, indolent, ignorant, weak and sensual." 186

Back in Puerto Rico, Federales noted Degetau's disappointing first term and made it part of their 1902 campaign. ${ }^{187}$ Remaining in the race, Federales won gains at the polls, reducing both the Republicano majority in the House of Delegates and Degetau's previously lopsided margin of victory. ${ }^{188}$ For Degetau, two years of arguing questions related to citizenship before federal administrators and other largely nonjudicial audiences had neither produced the recognition of Puerto Ricans as U.S. citizens that Degetau sought nor improved Degetau's electoral standing on the island. His approach required adjustment.

IV.

Degetau TURnS to Test CASES FOR CitIZENSHIP, 1902-1905

As Degetau contemplated the start of his second term in Washington as Resident Commissioner, he mustered his prior arguments to the U.S. public and federal officials behind new attempts to win U.S. citizenship, this time through judicial test cases. Here, as his faith in courts and law dovetailed with his failures to convince nonjudicial officials to vindicate his imperial-constitutional vision, Degetau came to treat courts as uniquely likely to hear and evaluate his claims.

185. Id. at 38-39; Porto Rican Land Bills Passed Senate, NEWS, June 26, 1902, CIHCAM 11/L4.

186. Prelate Vexes Porto Ricans, DET. J., June 2, 1902, CIHCAM 18/L1.

187. The Federales' candidate for resident commissioner Rafael Cuevas Zequeira, for instance, spoke of the need for a Puerto Rican representative in Washington who would fight hard and pursue outcomes other than just U.S. citizenship. Manifiesto del Sr. Cuebas, LA DEMOCRACIA, Oct. 28, 1902, at 1 (quoting Cuevas as asserting that he "will first and foremost demand U.S. citizenship for our people," but, failing that, that he "will energetically demand the inalienable right to be citizens of Puerto Rico" ("reclamaré muy especialmente la ciudadanía americana para nuestro pueblo"; "reclamaré enérgicamente al derecho inalienable a ser ... ciudadanos de Puerto Rico")).

188. BAYRON TORO, supra note 31, at 119-21. 
Degetau's first, best opportunity had already arisen. On August 2, 1902, the Treasury Department (then responsible for administering U.S. immigration laws) weighed in on the citizenship question at the heart of Degetau's constitutional vision by issuing a circular that categorized Puerto Ricans as aliens. ${ }^{189}$ Immigration authorities' jurisdiction expanded accordingly. Though islanders previously had "frequently disembarked unmolested in New York," they would now be "subject to the same examinations as are enforced against people from countries over which the United States claims no right of sovereignty." 190 The first application of the law came when the SS Philadelphia, which was already en route when the new policy issued, landed in New York, and officials held a Puerto Rican passenger named Isabel Gonzalez over for inspection at Ellis Island. ${ }^{191}$

Gonzalez confronted a powerful arm of the U.S. administrative state at Ellis Island. ${ }^{192}$ Exercising both prosecutorial and judicial functions, and insulated from most formal judicial review, hundreds of immigration inspectors determined the residence rights of as many as 5,000 immigrants per day. ${ }^{193}$ Their line inspections were standardized, high-volume, and summary. ${ }^{194}$ Immigration inspectors sent ambiguous cases before Boards of Special Inquiry that could end their nonpublic hearings in minutes and deny immigrants rights to an attorney or to see or rebut evidence. ${ }^{195}$ Several months earlier, William Williams, the well-regarded Wall Street lawyer, had become the new Commissioner of Immigration at Ellis Island. ${ }^{196}$ Concerned by what he perceived to be the "radical sociological, industrial, racial and intellectual distinctions" distinguishing northwestern and southeastern Europeans, Williams implemented policies that doubled the exclusion rate in his first

189. See Examination of Citizens and Residents of Porto Rico and the Philippine Islands Under Provisions of Immigration and Chinese-Exclusion Laws, Department Circular No. 97, Aug. 2, 1902, in Circular Instructions of the Treasury Department Relating to the TarifF, NAVIGATION, AND OTHER LAWS FOR THE YEAR ENDED DECEMBER 31, 1902 (1903) [hereinafter Circular No. 97].

190. Letter from Federico Degetau to Secretary of Treasury (Oct. 5, 1902), CIHCAM 3/VI/56; Circular No. 97, supra note 189.

191. Transcript of Record at 1, 3-6, Gonzales v. Williams, 192 U.S. 1 (1904) (No. 225) [hereinafter Gonzales Transcript]. I omit the accent marks in accordance with the usage of Isabel Gonzalez and her brother Luis Gonzalez in signing their names. See Letter from Isabel Gonzalez to Federico Degetau (Apr. 10, 1904), CIHCAM 5/I/5; Letter from Luis Gonzalez to Federico Degetau (Feb. 5, 1903), CIHCAM 3/VII/35.

192. See generally, e.g., ERIKA LEE, AT AMERICA'S GATES (2003) (drawing on federal immigration records to examine Chinese Exclusion, particularly in the years 1890-1925); LUCY E. SALYER, LAWS HARSH AS TIGERS 141-48 (1995) (describing immigration procedures); Louis Anthes, The Island of Duty: The Practice of Immigration Law on Ellis Island, 24 N.Y.U. REV. L. \& Soc. CHANGE 563 (1998) (describing administration of Ellis Island).

193. See SALYER, supra note 192, at 141, 144, 148, 184, 196-97.

194. See id. at 144-45, 147-48.

195. See id. at 141, 147-48.

196. Williams Regains Immigration Office, N.Y. TIMES, May 19, 1909, at 2; Letter from Secretary to the President to William Williams (Apr. 1, 1902), WWP, NYPL 1. 
year. ${ }^{197}$ Following Williams' policies, inspectors determined that Gonzalez was pregnant out of wedlock and excluded her as an undesirable "alien."198

Gonzalez responded by petitioning for a writ of habeas corpus before the U.S. Circuit Court for the Southern District of New York. ${ }^{199}$ Commissioner Williams realized that the case presented "the very difficult question of Constitutional law whether or not a Porto Rican was a citizen of the United States," and hired a private lawyer who, he later wrote, performed "exceedingly well." 200 On October 7, 1902, Judge E. Henry Lacombe announced his decision: because Gonzalez "was by birth an alien," he reasoned, she so remained, having not "in some appropriate way . . . since been naturalized." 201

Williams was thrilled. The Circuit Court had validated his policy and the legal analysis undergirding it, advanced his racial agenda, and confirmed his authority over recently annexed peoples. ${ }^{202}$ As he told a superior upon learning that a billing error made it likely that Williams would pay out of pocket the $\$ 250$ fee of the lawyer Williams had hired, "[s]uch loss will be very slight in comparison with the satisfaction of having secured a favorable decision for the Government in the Gonzalez case." ${ }^{203}$ Gonzalez sought review in the United States Supreme Court. ${ }^{204}$

After learning of the case in mid-October 1902, Degetau made the risky political decision to enter the litigation as amicus curiae. ${ }^{205}$ If the litigation produced no gains, it would provide Federales ammunition and isolate him from fellow Republicanos. Indeed, Speaker of the House of Delegates Manuel F. Rossy was already deriding Degetau's strategy: "[J]ust as your admission to the Supreme Court bar did not bring us citizenship," Rossy wrote Degetau, "your opinion" of how the system works "notwithstanding," U.S. citizenship "will have to be via legislation." 206

197. William Williams, Outline of Address Delivered to the Senior Class of Princeton (Nov. 1904), WWP, NYPL 6/4; SALYER, supra note 192, at 154.

198. Gonzales Transcript, supra note 191, at 2,6.

199. Id. at 1 .

200. Letter from William Williams to Henry Burnett, U.S. Attorney, New York City (Aug. 26, 1903), DC NARA 85/151/4 340/394/19045; Letter from William Williams to William F. Anderson, Esq. (Sep. 2, 1903), DC NARA 85/151/5 340/97/19045.

201. In re Gonzalez, 118 F. 941, 941 (C.C.S.D.N.Y. 1902)

202. On Williams's view that Puerto Ricans were aliens, see Letter from William Williams to Frederick R. Coudert Jr., Esq. (Dec. 16, 1903), DC NARA 85/151/12 340/4/19045; infra text accompanying notes 209-10.

203. Letter from William Williams to Commissioner-General of Immigration (Aug. 24, 1903), DC NARA 85/151/4 340/268/19045.

204. Gonzales Transcript, supra note 191, at 10.

205. See Brief Filed by Leave of the Court by Federico Degetau at 2, Gonzales v. Williams, 192 U.S. 1 (1904) (No. 225) [hereinafter Gonzales Amicus Brief].

206. Letter from Manuel Rossy to Federico Degetau (May 12, 1903), CIHCAM 4/II/176 ("como nada influyó su admision [sic] como Abogado ante el Tribunal Supremo, en lo referente á la ciudadania [sic]"; "a pesar de su opinion [sic], será mediante una ley”). 
Gonzalez's case, which rested on the question of her alienage, appeared likely to many to determine Puerto Ricans' citizenship status because of the widespread presumption that those not alien to the United States (i.e., U.S. nationals) were always also U.S. citizens. Degetau had made this assumption in his recent letter to Roosevelt. So too had Judge Lacombe when he had decided Gonzalez's case in the U.S. Circuit Court. But the equation was not inevitable. Frederic Coudert, the former lead lawyer in the 1901 Insular Cases, demonstrated as much in his 1903 Columbia Law Review article. Gonzalez should prevail in her appeal, Coudert argued, because Puerto Ricans were neither citizens nor "American aliens," but instead something in between: noncitizen U.S. nationals. ${ }^{207}$ The novelty of Coudert's suggestion was evident in the bafflement of his interlocutors. ${ }^{208}$ Commissioner Williams contested Coudert's claim that exclusion of Puerto Ricans like Gonzalez "ke[pt] out Americans from the country." 209 Assuring Coudert that immigration policies only applied to non-"Americans," Williams presumed that Coudert would agree with his use of "Americans as synonymous with U. S. citizens." ${ }^{210}$ Coudert's eventual client, Isabel Gonzalez, similarly denied that Puerto Ricans could sensibly be both noncitizens and non-aliens, decrying such a result as the "incongruous status" of "neither Americans nor foreigners." 211

Apparently exercising her prerogatives as litigant, Gonzalez secured from Coudert a brief to the Court consistent with her expressed desire that the case result in recognition of her and other Puerto Ricans as U.S. citizens. ${ }^{212}$ To make that case, which Coudert indicated would apply to Filipinos as well, Coudert portrayed U.S. citizenship as broadly distributed and of little consequence. ${ }^{213}$ Here, he reprised his argument from Downes v. Bidwell and DeLima v. Bidwell that the Fourteenth Amendment and international law gave all U.S. peoples, including "women, children[,] and all persons in the Territories," a "passive" or "naked" citizenship synonymous with U.S. nationality. ${ }^{214}$

Though American Indians and antebellum people of color occupied statuses intermediate between citizen and alien, Coudert cast those examples as

207. Coudert, supra note 36 , at 19-20.

208. In advocating that Puerto Ricans be neither citizens nor aliens, Coudert sought for Puerto Ricans an intermediate status quite like what Coudert described the Court as having already conferred upon Puerto Rico: classification both as "domestic territory" and as outside "the words "throughout the United States,' in the revenue clause of the Constitution." Id. at 20, 25. Consistent as his approach may have been with the prior Insular Cases, he lacked persuasive, positive U.S. precedents and turned instead to the practices of the British and French empires for support. See id. at 15-17, 29-32.

209. See Letter from Williams to Coudert, supra note 202 (quoting Letter from Frederic Coudert to William Williams (Dec. 15, 1903)).

210. See id.

211. Isabel Gonzalez, Sauce for Goose and Gander, N.Y. TIMES, Aug. 5, 1905, at 6.

212. See Brief of Petitioner-Appellant, Gonzales v. Williams, 192 U.S. 1 (1904) (No. 225) [hereinafter Gonzales Petitioner Brief].

213. Id. at 3.

214. Coudert's Downes Argument, supra note 99, at 41; Brief for Plaintiff in Error, at 88, 92 DeLima v. Bidwell, 182 U.S. 1 (1901) (No. 456) [hereinafter DeLima Plaintiffs Brief]. 
exceptional ones that bolstered his case. Indians' noncitizenship depended not on the status of where they were born but on a circumstance inapplicable to Puerto Rico: allegiance to a tribe rather than to the United States. ${ }^{215}$ That distinction provided a potential way to placate those like Democratic lawyerSenator Donelson Caffery of Louisiana, who worried that Filipinos "incapable of reaching our standard of government or civilization ... might inoculate our citizenship with the poison of theirs." ${ }^{216}$ As Coudert had already explained in Downes, the United States could class "uncivilized" Filipinos and American Indians as peoples owing tribal allegiances that rendered them peculiarly ineligible for Fourteenth Amendment citizenship. ${ }^{217}$

In discussing the classification of antebellum people of color as noncitizens in the Dred Scott case, Coudert also built on arguments he had presented to the Court in Downes. There, Coudert had contended that Chief Justice Roger Taney's analysis had stressed how free blacks were "capable of being made property." "18 They had been, Coudert had concluded, constitutionally "different and apart from the rest of humanity," "half man, half beast." 219 Stressing that Puerto Ricans did not "occupy that debased position," he had reminded the Court that Taney's "views have been repudiated by the American people in the Civil War, by three amendments to the Constitution of the United States, by this court, and by forty years of advancing civilization. ${ }^{, 220}$ Now he added that finding Puerto Ricans to be other than U.S. citizens would require, through "recourse to the two precedents in our history of which we are least proud," "a repetition of [those cases'] peculiar, and, from a standard of American civilization, most anomalous result.",221

In his amicus brief to the Court in Gonzales, Federico Degetau took a dramatically different approach. As a former Spanish citizen, he associated his island with markings of male honor like economic self-sufficiency, martial experience, and exercise of political and civil rights. Reinterpreting rather than rejecting colonial and expansionist precedents, he drew imperial and crosscultural comparisons. He did not seek "passive" U.S. citizenship akin to that enjoyed by women and people of color, nor did he seek to gain active citizenship for other colonized and marginalized people. Instead, he deprecated

215. See Gonzales Petitioner Brief, supra note 212, at 6; see also Coudert's Downes Argument, supra note 99, at 42-44; DeLima Plaintiffs Brief, supra note 214, at 77-99.

216. Caffery on the Philippines, N.Y. TIMES, Feb. 7, 1900, at 5. Caffery left the Senate in 1901. Biographical Directory of the United States Congress 1774 - Present, supra note 124.

217. See U.S. CONST. amend. XIV, § 1; supra note 215.

218. Coudert's Downes Argument, supra note 99, at 43. On antebellum re-enslavement, see generally IRA BERLIN, SLAVES WITHOUT MASTERS 370-80 passim (1974); Rebecca J. Scott, Paper Thin: Freedom and Re-enslavement in the Diaspora of the Haitian Revolution, 29 L. \& HIST. REV. 1061 (2011).

219. DeLima Plaintiffs Brief, supra note 214, at 95, 84.

220. Coudert's Downes Argument, supra note 99, at 43; DeLima Plaintiffs Brief, supra note 214 , at 99 .

221. Gonzales Petitioner Brief, supra note 212, at 39. 
members of other groups to claim for Puerto Ricans like himself a robust U.S. citizenship associated with white men, civilization, economic and legal opportunities, political participation, and military and tax obligations. In fact, he argued, while drawing on his experiences with U.S. officials before and during his first term, Puerto Ricans already occupied these roles.

Key to Degetau's argument was the contention that Puerto Ricans were not "natives" in the colonial sense. When the Treaty of Paris vested Congress with discretion to determine the citizenship status of "native inhabitants" of Spain's former possessions, he wrote, it referred to "the uncivilized tribes of the Philippine Islands" and not "Spanish citizens born in Porto Rico."222 Those citizens, he elaborated, had enjoyed such rights as representation in the national legislature, national citizenship accompanied by constitutional protections, "the same honors and prerogatives as the native-born in Castille," and broad autonomy. ${ }^{223}$ This attempt to conflate the status of those Puerto Ricans born in continental Spain with those born on the island tracked a goal that predominantly island-born liberal-autonomists had long pursued but not achieved during Spanish rule. Through this argument, Degetau also aimed to position Puerto Rico favorably within the broader context of historical U.S. expansion. He claimed that Puerto Ricans differed from ostensibly and implicitly inferior Filipino "tribes," "Mongolians," and the "uncivilized native tribes [of] Alaska." $224 \mathrm{He}$ also distinguished American Indians, whoinexplicably, he implied - could become U.S. citizens by renouncing tribal allegiances while Puerto Ricans could not because they had no foreign allegiance to renounce. ${ }^{225}$ Instead, he indicated, Puerto Ricans resembled the French and Mexicans who had been incorporated into U.S. citizenship in earlier U.S. cessions. Along these lines, he emphasized that islanders already paid U.S. taxes, swore allegiance to the U.S. Constitution and laws, were soon likely to elect a nonvoting delegate to the House of Representatives, and were Americans and citizens of a U.S. territory. ${ }^{226}$

Attempting to boost his countrymen at others' expense in another way, Degetau sought to distinguish what he depicted as the active Puerto Rican citizenry from Cubans and Filipinos. President McKinley, using language that could have described a marriage contract, had Cubans in 1898 grant their "honest submission" to receive from the United States "support and protection." 227 And, using language suggestive of a parent-child relationship, he had Filipinos swear to "recognize[] and accept[] the supreme authority of the

222. Treaty of Peace, supra note 11; Gonzales Amicus Brief, supra note 205, at 30.

223. Gonzales Amicus Brief, supra note 205, at 18 (citing as the source of the quotation “Zamora y Coronado, 'Legislación Ultramarina,' Tomo I, p. 255-257”), 19-22, 27-29, 36.

224. Id. at 28 (citing as the source of the quotation "Foreign Relations of the United States, 1898. Correspondence with the United States Peace Commissioners p. 961").

225. Id. at 33-36.

226. Id. at 21-22,33-34.

227. Id. at 25-26. 
United States." 228 By contrast, prospective Puerto Rican officeholders (including Degetau) renounced their allegiance to Spain and agreed to "support and defend the Constitution of the United States against all enemies home or foreign." 229 This, Degetau claimed, effected "a plain renunciation of all foreign allegiance and an explicit acceptance of the duties of American citizenship."230 The oath invoked male realms of political rights and participation by referring to defending the nation from foreign enemies, occupying political office, and upholding the U.S. Constitution. Taken together, Degetau's comparisons implied that Cuba agreed to receive protection from the United States like a wife; the Philippines accepted the authority of the United States like a child; and Puerto Rico swore allegiance to and took up the defense of the United States, like a man.

Degetau portrayed an island population that actively and naturally blended into the United States and that deserved legal and professional opportunities open only to U.S. citizens. Under the Foraker Act, he explained, mainlanders resident in Puerto Rico, along with all Puerto Ricans, constituted a single body politic - the people of Puerto Rico. ${ }^{231}$ Since mainlanders retained their U.S. citizenship even after becoming part of the people of Puerto Rico, which he treated as equivalent to becoming a citizen of Puerto Rico, Puerto Rican citizenship could not be an alternative to U.S. citizenship. ${ }^{232}$ Thus, Degetau argued, Puerto Rican citizenship was territorial citizenship, coexisting with Fourteenth Amendment birthright citizenship. ${ }^{233}$ Puerto Ricans also needed U.S. citizenship to exercise autonomy and control within business and law, which Degetau highlighted by noting federal requirements that ship captains, bank directors, and prosecuting litigants in the Court of Claims be U.S. citizens. $^{234}$

Degetau's arguments implicitly asked the court to consider him, an accomplished civil servant, rather than Gonzalez, an unmarried mother, as the model for Puerto Rican citizenship. He closed on a personal note, reprising one of his earlier gambits: "If I were an alien, I could not have attained the highest honor in my professional career, that of taking, as a member of the bar of this Honorable Court, the oath to maintain the Constitution of the United States, this oath being incompatible with allegiance to any other power ...."235

At oral argument on December 4, 1903, the Supreme Court appeared to agree with Degetau - at least in part. According to one observer, Chief Justice Melville Fuller dismissed the contention that Degetau's admission to the

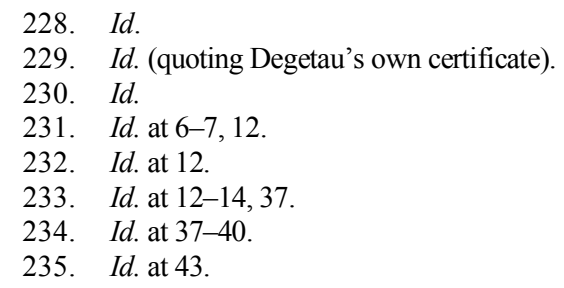


Court's bar was "by courtesy" rather than "by right," at which point the Solicitor General all but conceded that Puerto Ricans could not be aliens. ${ }^{236}$

It was less clear whether the Justices believed that islanders were U.S. citizens. When Coudert cast denial of citizenship as monarchical "subjection" best known to U.S. law through its association with Dred Scott, Justice William Day objected, indicating a preference for a less charged term like "liegemen." 237 Justice Day apparently wanted to decline Coudert's proposal that the Court recognize a relatively modest version of U.S. citizenship and thereby avoid creating U.S. subjects or new rights for Puerto Ricans. ${ }^{238}$ Though Day was reluctant to acknowledge explicitly that the Court had drained much meaning from U.S. citizenship, that did not mean he had qualms about U.S. treatment of women, people of color, or colonized peoples. In Downes, for instance, Justice White had depicted U.S. citizenship as a status rich in rights without addressing the ways that unequal U.S. treatment of women and people of color appeared to belie that claim.

On January 4, 1904, Chief Justice Fuller announced the unanimous and narrow holding of the Court: "[W] ... cannot concede ... that the word 'alien,' as used in the [immigration] act of 1891, embraces the citizens of Porto Rico." ${ }^{239}$ His reasoning tracked that of both Bureau of Insular Affairs Law Officer Charles Magoon, who had argued prior to passage of the Foraker Act that islanders would only have the right to enter the United States if a federal law made the island into a part of the United States, and Degetau, who had focused on particularities of U.S.-Puerto Rican relations. Relying in part on acts of the political branches, such as the Treaty of Paris and Foraker Act, Fuller explained that the United States had made "[t]he nationality of the island ... American" and integrated Puerto Rico into the United States. ${ }^{240}$ In Puerto Rico, the United States had created a civil government with heads named by the U.S. President, implemented congressional oversight, established a U.S. district court, run judicial process in the name of the U.S. President, nationalized Puerto Rican vessels, and put most U.S. statutes into force. ${ }^{241}$ Degetau had hoped that arguments tightly focused on Puerto Rico might secure from the Court a particular incremental result: U.S. citizenship for Puerto Ricans on grounds not necessarily applicable to the Philippines. The Court,

236. Pedro García Olivieri, Letter to Editor, Puerto Rico en la Corte Suprema Nacional, P.R. HERALD, Dec. 12, 1903, at 1127 ("admitido por cortesía del”; "el Comisionado estaba allí por su derecho").

237. Argument of Frederic R. Coudert, Jr., Esq., on Behalf of the Petitioner-Appellant at 49, 53-56 passim Gonzales v. Williams, 192 U.S. 1 (1904) (No. 225).

238. For more on Coudert and his client, Isabel Gonzalez, see Christina Duffy Burnett, "They say I am not an American ...": The Noncitizen National and the Law of American Empire, 48 VA. J. INT'L L. 659 (2008); Erman, supra note 29, at 29-32; Erman, supra note 15, at 77-195.

239. Gonzales v. Williams, 192 U.S. 1, 12 (1904).

240. Id. at 8-15.

241. See id. at 10-11. 
however, ruled more incrementally still. It found that the Treasury Department guideline under which Gonzalez had been held was invalid, while avoiding the issue of whether Congress had the power to implement similar rules. ${ }^{242}$

And as to whether Puerto Ricans were U.S. citizens, nationals, subjects, or liegemen, Fuller wrote: "We are not required to discuss ... the contention of Gonzales's counsel that the cession of Porto Rico accomplished the naturalization of its people; or that of Commissioner Degetau, in his excellent argument." 243 Having struck down the outlier Treasury Department position that Puerto Ricans were aliens, the justices joined the numerous administrators who found it profitable to evade clarifying the U.S. citizenship status of Puerto Ricans, even at the expense of conceding islanders rights. ${ }^{244}$ The strategic silence rested on the possibility of a status intermediate to citizen and alien. It avoided openly contradicting the widely held belief that U.S. citizenship and U.S. nationality were coextensive, while leaving lawmakers and administrators room to maneuver in the control of new territorial acquisitions. Potentially signaling reluctance by the Court to declare Puerto Ricans or Filipinos to be U.S. citizens, the decision became to some an invitation to decide the matter politically and administratively. ${ }^{245}$ As in Downes, vagueness proved valuable to the Court as it sought to accommodate U.S. empire and constitutional democracy. ${ }^{246}$

For Degetau, judicial vagueness served no ends, even when coupled as in Gonzales with an expansion of Puerto Rican rights. He had campaigned on the promise of winning U.S. citizenship for Puerto Ricans and, through that step, constitutional rights and recognition of Puerto Rico as a traditional U.S territory on the road to statehood. With clarification of islanders' citizenship status apparently stymied, Degetau's long-sought goal seemed further from reach than ever. The decision also isolated Degetau from fellow Republicanos. According to party leader Manuel Rossy, the case "did not interest opinion ... because everyone expected what occurred." ${ }^{, 47}$ Afterward, others began preparing to challenge Degetau for the party's nomination. ${ }^{248}$ Having gone all in, Degetau stayed in Washington to play what remained of his hand. ${ }^{249}$

242. See id. at 12,15 .

243. Id. at 12 .

244. On courts and constitutional outliers, see, e.g., Michael J. KLARman, From the CLOSET TO THE ALTAR 205 (2013); WhitTINGTON, supra note 15, at 105; Keck, supra note 7, at 528.

245. See infra text accompanying, discussion within, and external authorities in notes 295300, 303-05, 355-56.

246. See supra note 22 and accompanying text.

247. Letter from Manuel Rossy to Federico Degetau (Jan. 26, 1904), CIHCAM 4/VIII/14 ("no interesó á la opinión"; "así la esperaban todos").

248. Letter from [Illegible] to Federico Degetau (May 7, 1904), CIHCAM 5/I/25; see Scandal at Mayaguez, WASH. Post, Apr. 19, 1903, at 1; Plans a Surprise in Porto Rico, CHI. DAILY TRIB., July 25,1898 , at 1 .

249. See Draft, Letter from Federico Degetau to Mr. Henry (June 1904), CIHCAM 5/II/8; see also Erman, supra note 15, at 180. 
Five days after the Gonzalez decision, Degetau launched a new campaign in hopes of making the case "a stepping stone to a more decided recognition of the rights of Puerto Ricans in the United States." ${ }^{250}$ On January 9, 1904, he wrote the Board of Election Commissioners in Chicago about the voting rights of Puerto Ricans in the city. ${ }^{251}$ Board attorney William Wheelock replied that he had recently refused to register Puerto Ricans because he deemed them noncitizens. ${ }^{252}$ Sending Wheelock his Amicus Brief in Gonzales and a copy of the decision, Degetau asked him to reconsider. ${ }^{253}$ In a February 23 letter to Degetau, Wheelock affirmed his view that Puerto Ricans were not U.S. citizens, Gonzales notwithstanding. ${ }^{254}$ Wheelock quickly added that he had no record of the identities of the potential test-case litigants. ${ }^{255}$

In the midst of his correspondence with Wheelock, Degetau separately won floor privileges in the House of Representatives, though still no vote. ${ }^{256}$ Because the Senate continued to refuse to act, Degetau remained a Resident Commissioner and did not join representatives of traditional territories as a fellow "delegate." ${ }^{257}$ Undeterred, he used his new powers to introduce a bill in the House to declare islanders to be U.S. citizens. ${ }^{258}$

Two weeks later, a new test case took shape when Juan Rodríguez, a nineteen-year-old native of Puerto Rico, requested that the Board of Labor Employment at the U.S. Navy Yard register him as a job candidate. ${ }^{259}$ Navyyard rules stated that "[n]o applicant will be registered unless ... he is a citizen of the United States," so Rodríguez's application appeared to raise the question that the Gonzales Court had reserved. ${ }^{260}$ President Roosevelt had tried to avoid such problems by declaring that "birth or naturalization in Porto Rico" would also suffice. ${ }^{261}$ But as government lawyers would soon argue, Roosevelt's rule could be read not to reach the job that Rodríguez sought. ${ }^{262}$ After the Assistant

250. Puerto Ricans Admitted, P.R. HERALD, Jan. 9, 1904, at 1188; Letter from W. W. Wheelock to Federico Degetau (Jan. 14, 1904), CIHCAM 4/VIII/11.

251. Letter from Wheelock to Degetau, supra note 250.

252. Id.

253. Letter from W. W. Wheelock to Frederico [sic] Degetau (Feb. 23, 1904), CIHCAM 4/VIII/39.

254. Id.

255. Id.; see also Letter from W.W. Wheelock to Federico Degetau (Feb. 26, 1904), CIHCAM $4 / \mathrm{VIII} / 41$

256. Delegate from Porto Rico, N.Y. TIMES, Feb. 3, 1904, at 6.

257. Id.; Federico Degetau, The Constitution AND the Flag IN Porto Rico (1905), CIHCAM 6/L10; Letter from Federico Degetau to Joseph W. Babcock [Copy] (May 30, 1904), CIHCAM 5/I/35

258. See H.R. 11592, 58th Cong., 2nd Sess., 38 CONG. REC. 2554 (1904), CIHCAM 4/VIII/19; see also Delegate from Porto Rico, supra note 256.

259. Transcript of Record at 4-11, Rodriguez v. Bowyer, 25 App. D.C. 121 (1905) (No. 1504—No. 8 Special Calendar) [hereinafter Rodriguez Transcript], CIHCAM 6/VI/32.

260. Brief for Appellant at 7, Rodriguez v. Bowyer, 25 App. D.C. 121 (1905) (No. 1504 -No. 8 Special Calendar) [hereinafter Rodriguez Appellant Brief], CIHCAM 6/VI/33.

261. Id. at 5 .

262. Brief for Appellees at 11-13, Rodriguez v. Bowyer, 25 App. D.C. 121 (1905) (No. 1504 -No. 8 Special Calendar), CIHCAM 6/VI/34. 
Secretary of the Navy - himself a lawyer - concluded "that as Mr. Rodríguez is not a citizen of the United States he is not eligible for registration," the board deferred to that legal view and denied the application. ${ }^{263}$

Rodríguez's rejected application for navy-yard employment thus became a promising test case. Degetau launched it in the Supreme Court of the District of Columbia by filing a petition for mandamus seeking to compel the navy-yard board to register Rodríguez. ${ }^{264}$

When Degetau finally returned to San Juan in late June $1904,{ }^{265}$ his political isolation was palpable. Weeks earlier, he had declined membership in a committee of the Republican Caucus of the U.S. House of Representatives because he "did not deem it entirely consistent ... to take a side in the internal differences of our national political parties" "so long as [he] was not recognized as a citizen of the United States, and was called 'Resident Commissioner.",266 In the interim, Republicanos had sent delegates to the Republican National Convention, where they secured two votes. ${ }^{267}$ In island political speeches on "the status of Puerto Rico," the opposition paper La Democracia reported, Degetau continued to argue "that the Supreme Court in Washington had to determine it." ${ }^{, 68}$ Like many Republicanos, La Democracia disagreed: "Few share this opinion" of Degetau's, it reported, for many "express the view that it is the National Congress that can and should take action concerning American citizenship." 269

As summer gave way to fall, Republicanos declined to nominate Degetau for a third term. ${ }^{270}$ Seeing opportunity in Republicanos' disappointment and division, Federales reconstituted themselves as an umbrella Partido Unionista. ${ }^{271}$ The new party sought self-government, be it as a state of the Union, U.S. territory, or independent nation. And it embraced more

263. Rodriguez Transcript, supra note 259, at 7; see also 1 MEN OF MARK IN AMERICA 274 (Merrill E. Gates ed., 1905).

264. Rodriguez Transcript, supra note 259, at 3.

265. D. Federico Degetau y González, LA DeMOCRACIA, June 24, 1904, at 2.

266. Letter from Degetau to Babcock, supra note 257.

267. See Informe de los delegados del Partido Republicano de Puerto Rico ante LA CONVENCIÓN NACIONAL REPUBLICANA CELEBRADA EN CHICAGO, EN 21 DE JUNIO DE 1904 19-21 passim (1904), CIHCAM 6/L8; D. Federico Degetau y González, supra note 265.

268. El señor Degetau dio una conferencia en Ponce, LA DEMOCRACIA, Aug. 1, 1904, at 2 ("el status de Puerto-Rico, manifestando que es la Corte Suprema de Washington la que ha de determinarlo").

269. Id. ("De esta opinión del señor Degetau no son muchos aquí, que opinan que es el Congreso Nacional el que puede y debe tomar acuerdo sobre la ciudadanía americana"). As to whether recognition of Puerto Ricans as U.S. citizens would bring recognition of Puerto Rico as a traditional U.S. territory, see Torruella, supra note 48, at 314 (arguing that Hawaii v. Mankichi, 190 U.S. 197 (1903), established as much).

270. See Candidatura republicana, LA Democracia, Sept. 19, 1904, at 1; Porto Rican Nominations, WASH. POST, Oct. 11, 1904, at 4; Letter from A. Navarrete to Federico Degetau (Sep. 30, 1904), CIHCAM 5/II/17.

271. Asamblea para constituir la Unión de Puerto Rico, P.R. HERALD, Mar. 5, 1904, at 1317. 
confrontational rhetoric than Republicanos had deployed. ${ }^{272}$ On November 8, 1904, Unionistas came to power, capturing the House of Delegates and the Resident Commissionership. ${ }^{273}$

Degetau returned to Washington to use his final days as Resident Commissioner to continue his activism in support of U.S. citizenship for Puerto Ricans. ${ }^{274}$ When the Supreme Court of the District of Columbia on December 12 denied the petition that Degetau had filed for Rodríguez, Degetau and his client appealed. ${ }^{275}$ Degetau then made a final speech on the floor of the House of Representatives seeking U.S. citizenship for Puerto Ricans. ${ }^{276}$

In mid-February, Degetau filed his brief on Rodriguez's behalf before the Court of Appeals of the District of Columbia. ${ }^{277}$ Implicitly acknowledging the pull of Coudert's earlier arguments, Degetau addressed the suggestion that Puerto Ricans be recognized as noncitizen U.S. nationals and adopted the proposal that the Court recognize islanders as holders of a relatively inconsequential U.S. citizenship. Having largely presumed in Gonzales that Puerto Ricans were either aliens or citizens, Degetau now made the argument explicit. He wrote that Congress had made most federal statutes applicable in Puerto Rico. Noting that these statutes included many referring to U.S. citizens and "not ... "nationals," he argued that the decision indicated a congressional belief that Puerto Ricans were U.S. citizens. ${ }^{278}$ Noting that the Supreme Court had "declared that Porto Rico is a territory of the United States," he also asserted that Puerto Ricans were U.S. citizens under a federal statute declaring "“[a]ll persons born in the United States [with irrelevant exceptions] ... to be citizens of the United States.",279

Despite his portrayals in Gonzales of Puerto Ricans as independent, militarily and legislatively experienced male citizens, Degetau now deployed Coudert's depiction of U.S. citizenship as widely distributed and relatively modest in its implications. The "middle ground" of being a "national[]" but not a citizen "does not exist" under the U.S. "constitutional organization," Degetau told the court, for unlike France or Spain "[o]ur constitution is not based on the principle of the sovereignty of the nation"; it is " [w]e the people" who "“ordain and establish" it. $^{280}$ The implication was that U.S. citizenship encompassed Filipinos as well as Puerto Ricans. But such universal

272. See CABÁN, supra note 13, at 184; De cómo puede hacerse la unión, P.R. HERALD, Jan. 9, 1904, at 1191; Ponce viene á 'LA UNIÓN, 'LA DeMOCRACIA, Aug. 1, 1904, at 1.

273. BAYRON TORO, supra note 31, at 125-26.

274. El señor Degetau, LA DEMOCRACIA, Nov. 29, 1904, at 2.

275. Rodriguez Transcript, supra note 259, at 8-10.

276. DEGETAU, supra note 257.

277. See The Legal Record, WASH. POST, Feb. 8, 1905, at 9; Porto Rican Eligible, WASH. PosT, Mar. 8, 1905, at 6.

278. Rodriguez Appellant Brief, supra note 260.

279. Id. at 11 .

280. Id. (quoting U.S. CONST. pmbl.). 
citizenship did not mean universal rights, Degetau assured the court. Citing the " "minors and married women" who were U.S. citizens, he insisted "that political privileges are not essential to citizenship."281

Degetau's final attempts to win citizenship as Resident Commissioner proved unavailing. On March 4, Congress adjourned the 1903-1905 term, ending Degetau's tenure as Resident Commissioner without making him a Delegate or Puerto Ricans U.S. citizens. ${ }^{282}$ Three days later, the Court of Appeals for the District of Columbia lifted a page from Gonzales and ruled for Rodríguez on noncitizenship grounds. President Roosevelt's instructions that those demonstrating Puerto Rican citizenship "will not be required to show further evidence of citizenship," it held, applied. ${ }^{283}$

Among Puerto Ricans, Federico Degetau had unrivaled influence in Washington during the first half-dozen years of U.S. rule of his island. Nonetheless, his efforts as Resident Commissioner were, by most measures, failures. Five years of efforts had produced little progress on Degetau's campaign promises to secure Puerto Ricans U.S. citizenship, full constitutional protections, and residence in a traditional U.S. territory on the way to statehood. Rather, the United States consolidated a colonial regime in Puerto Rico on his watch. Neither federal policymakers nor U.S. adjudicative officials recognized Puerto Ricans as U.S. citizens, and statehood seemed less likely in 1905 than it had in $1899 .^{284}$

$\mathrm{V}$.

\section{Post-Degetau Politics and Constitutional Settlement}

Though Degetau's turn at the center of Puerto Rican politics had ended by 1905 , the struggles in which he participated and the dynamics he helped animate continued, as the following brief overview illuminates. ${ }^{285}$ Beginning in 1905, Degetau's now-dominant Unionista opponents launched a dozen-yearlong political campaign for greater self-government. They joined U.S. officials on the island, War Department administrators, and congressmen in debates over U.S. policy in Puerto Rico. As they did so, a conventional wisdom developed that was built upon the ambiguous doctrinal innovations that Degetau's activities had helped bring about. It held that the Supreme Court was unwilling

281. Id. at 16 (citing as the source of the nested quotation "Monsieur de Cogordan, in his book on 'French Nationality").

282. See 38 CONG. ReC. [House Bills] 307 (1904); 39 CONG. ReC. [House Bills] 87 (1905); Congress at an End, WASH. POST, Mar. 5, 1905, at 6.

283. Porto Rican Eligible, supra note 277, at 6 (citing the source of the quotation as "Rule 5" "of the civil service" "commission"); see Rodriguez v. Bowyer, 25 App. D.C. 121, 124 (D.C. Cir. 1905).

284. Degetau initially succeeded and ultimately failed to use litigation to expand his political movement, garner support for it, and leverage his other political tactics. See Skrentny, supra note 131, at 231 (suggesting the possibility of these benefits of litigation).

285. Erman, supra note 15, at 196-277, elaborates. 
to declare Puerto Ricans to be U.S. citizens, that the status would bring Puerto Ricans no new rights, and that Puerto Ricans could not expect more than modest extensions of self-government. The Court played little role in these developments in 1905-1917. Only in the 1920s did the Court begin expressly recognizing the status relationships and legal frameworks within which lawmakers, Puerto Ricans, and U.S. administrators had worked.

In the years after 1905, Degetau largely withdrew from U.S. and island politics and instead cultivated his coffee farm. ${ }^{286}$ "I have now nearly completely retired from public life" to the mountainous island interior, he wrote in $1910 .^{287}$ In retrospect, he still counted "the high distinction of appearing before the U.S. Supreme Court" as among his greatest accomplishments during his fight as Resident Commissioner to win for islanders "definition of our status as American citizens." 288 In 1914, after succumbing to a longstanding and mysterious malady, Degetau was laid to rest in a Puerto Rican homeland that held a status within the U.S. empire-state as uncertain as his own status remained. ${ }^{289}$

As the ambiguity in Puerto Ricans' status at the core of Degetau's experience of U.S. empire persisted, others-particularly now-dominant Unionistas - took up the fight with U.S. officials over the island's proper place in the U.S. order. ${ }^{290}$ After more staid tactics failed in 1905-1908 to win from the Republican-controlled U.S. political branches greater self-government for Puerto Rico, the Unionista-controlled House of Delegates moved to transform the stage of the debate. ${ }^{291}$ In 1909 , to protest lack of Puerto Rican participation in island governance, the delegates refused to pass a budget. ${ }^{292}$ With government shutdown looming absent the new budget, the federal political branches enacted legislation that left the prior budget in place until a subsequent one replaced it. ${ }^{293}$ The law also authorized renewed oversight of the

286. Letter from Federico Degetau to Pedro Salazar (June 16, 1909), CIHCAM 10/II/26.

287. Draft, Letter from Federico Degetau to Julio Gonzalez Pola (Dec. 6, 1910), CIHCAM 5/IV/15 ("Retirado yo ya de la vida pública casi por completo").

288. William Jennings Bryan, et al., El Paso de Mr. BRyan por SAN Juan 24-25 (1910) ("de adquirir de ellos poderes, por la definición de nuestro status como ciudadanos americanos"; "habiendo sido objeto de la alta distinción recibida del Tribunal Supremo de los Estados Unidos"); see Draft Letter from Degetau to Gonzalez Pola, supra note 287.

289. Personales $y$ de sociedad, GrafiCO, Jan. 24, 1914, CIHCAM 17/IV/5; Letter from Federico Degetau to "My dear Brother" (Oct. 13, 1913), CIHCAM 5/V/16.

290. See BAYRON TORO, supra note 31, at 123-57. Among myriad examples of scholarship on colonized peoples' experiences occupying ambiguous statuses, see Burnett, supra note 238, at 684; Erman, supra note 15.

291. See, e.g., Erman, supra note 15, at 216-18.

292. See Comisión de la cámara en Washington, LA DeMOCRACiA, Apr. 2, 1909, at 1; Brief, Luis Muñoz Rivera et al., reprinted in 44 CONG. REC. 4337-47 (1909); 44 CONG. REC. 2340-46; Memorandum of W. F. Willoughby et al. to Secretary of the Interior, Mar. 29, 1909, in S. REP. No. 6110, at 9-11 (1910); Memorandum of Régis H. Post to Secretary of the Interior, Mar. 17, 1909, in S. REP. NO. 61-10, at 6-7 (1910).

293. See supra note 292. 
island and its government by the Bureau of Insular Affairs. ${ }^{294}$ Bureau officials in Washington thus joined presidential appointees on the island, federal lawmakers, and elected Puerto Ricans at the center of debates on U.S.-Puerto Rican relations.

At newly elected Republican President William Taft's request, War Department officials began to investigate potential reforms for Puerto Rico in late $1909 .{ }^{295}$ Among their discoveries, U.S. citizenship no longer carried with it the "great powers, rights, privileges, and immunities" that Bureau Law Officer Charles Magoon had perceived in it in 1900. In this, Degetau had played a meaningful role. As officials had met his claims to rights associated with citizenship by extending Puerto Ricans those rights independent of their citizenship status, the rights that islanders could expect to gain if they became U.S. citizens had diminished. As early as 1905, the Republican Secretary and future-Governor of Puerto Rico Regis Post — who had previously studied law and who sought to influence federal legislation - had speculated that U.S. citizenship would be a "perfectly empty gift." 296 It would not, he had written, threaten "any of our control" or extend islanders new rights. ${ }^{297}$ But, he added, it would placate Puerto Ricans who "consider [noncitizenship] rather a slur on their honor." ${ }^{298}$ On December 21, 1909, new Bureau Law Officer Paul Charlton agreed in a legal memo that he sent up the chain of command. Reflecting the extent to which rights had already been delinked from U.S. citizenship, he wrote that the

"only rights which a citizen ... acquires by reason of his federal citizenship are: (1) The protection of the United States ... by a passport ... ; and (2) Access to the federal Courts[, b]oth ... rights . . . uniformly possessed by citizens of Porto Rico."299

U.S. citizenship, he concluded, could be safely extended to Puerto Ricans. War Department officials soon publicly advocated for the same. ${ }^{300}$

294. Message from President Wm. H. Taft to Senate and House of Representatives, May 10, 1909, in S. REP. NO. 61-10, at 1-5 (1910); see 44 CONG. REC. [House Bills] 315 (1909); CHAUNCEY M. DePew, 7 Orations, AdDRESSES AND SPeEChes of ChaunCEY M. DePeW 331 (John Denison Champlin ed., 1910); La cuestión de Puerto-Rico, LA DEMOCRACIA, May [24?], 1909, at 2.

295. See Hearings Upon the Bill Proposing to Amend the Present Organic Law of Porto Rico: Hearing Before the H. Comm. on Insular Affairs, 61st Cong., at 16 (1910), MD NARA 350/5A/339/3377-28.

296. Letter of Secretary Post, supra note 19, at 2 (1906); see Regis Henri Post Sr., Marries in Paris, N.Y. Times, Apr. 6, 1933, at 21; Rich American in the Porto Rico Palace, Bos. DAily Globe, Mar. 24, 1907, at 44.

297. Letter of Secretary Post, supra note 19, at 2.

298. Id.

299. Memorandum from Paul Charlton to General Edwards, Secretary of War, at 3 (Dec. 21, 1909), MD NARA 350/5B/180G/1286-11.

300. See For Elective Citizenship, WASH. Post, May 4, 1910, at 5; Porto Ricans in City, WASH. Post, Apr. 27, 1910, at 4; Taft's Message Urges Reforms, CHI. DAILY TRIB., Dec. 7, 1910, at A15; Copy, Santiago Iglesias, [Title unknown], UniÓN OBRERA, Apr. 29, 1910, CDO:1; Cablegram from Colton to Secretary (Mar. 25, 1910), CDO:1; Cablegram from Colton to Dickinson (Apr. 15, 
Although Unionistas did not oppose U.S. citizenship in 1910, greater selfgovernment remained their priority. Unlike Degetau, they focused their advocacy on administrators and political officials to the relative exclusion of courts. Seeking to present the Republican-controlled Congress a united front, Unionistas and Republican administrators of Puerto Rico crafted a joint compromise proposal that envisioned collective naturalization of Puerto Ricans, a fully elected island legislature, and an absolute governmental veto. ${ }^{301}$ In June 1910, the House of Representatives passed a bill roughly along those lines. ${ }^{302}$ Late in the term, the Senate Committee on Pacific Islands and Porto Rico recommended similar action, observing that litigants had repeatedly and unavailingly asked the Supreme Court to determine the U.S. citizenship status of Puerto Ricans. ${ }^{303}$ The committee singled out the case in which Degetau had participated for special comment: Because "the Chief Justice [in Gonzales] intimat[ed] in regard to that question that the court will not seek a ford until it comes to the stream," 304 the question was ripe for political resolution. "[T]o all intents and purposes, the Porto Rican people are not citizens of the United States." ${ }^{305}$ The Senate as a whole, however, did not act before the expiration of the term, and the bill died. ${ }^{306}$ Democrats then took control of the House of Representatives in 1911, creating a divided federal government that declined to enact Puerto Rican reform. ${ }^{307}$

Proposals for Puerto Rican reform reemerged in 1913 when the political landscape again shifted as Democrats took control of the federal political branches for only the second time since the Civil War. ${ }^{308}$ The fate of Puerto Rico in the House of Representatives now lay in the hands of the Committee on

1910), MD NARA 350/5A/341/3377-82; Telegram from Colton to President Taft (Apr. 20, 1910), MD NARA 350/5A/341/3377-85; Cablegram from Colton to Dickinson (Apr. 10, 1910), MD NARA 350/5A/341/3377-84; Memorandum of [George Colton] ([Apr. or May 1910]), MD NARA $350 / 5 \mathrm{~A} / 341 / 3377-86$.

301. See supra, note 300 .

302. Cabranes, supra note 13, at 457.

303. S. REP. NO. 61-920, at 2 (1910).

304. Id.

305. Id. Contemporaries saw Gonzales as a leading case on the status of acquired peoples. See, e.g., H. EdGar Barnes \& Byron A. Milner, Selected Cases in Constitutional LaW 214-15 (4th ed. 1913) (including an abridged version of the Gonzales opinion among highlighted cases); JAMES PARKER HALl, CONSTITUTIONAL LAW 73 (1910) (citing Gonzales in classifying U.S. colonized peoples as noncitizen nationals). Not so many scholars. Some accord the case little attention. See Burnett, supra note 238, at 661-62 \& n.8 (discussing the scholarship addressing Gonzalez). Others misread Gonzalez as denying U.S. citizenship. See RIVERA RAMOS, supra note 13, at 4; CARLOS R. SOLTERO, LATINOS AND AMERICAN LAW 24 (2006); Dick THORNBURGH, PUERTO Rico's FutURE 49 (2007); OfFice of Directives Management, U.S. DeP'T of State, 7 U.S. DeP'T OF State FOREIGN AFFAIRS MANUAL 1121.2-2 (1996), http:/www.state.gov/documents/organization/ 86756.pdf. Still others construe the case as having introduced noncitizen nationality into U.S. law despite the absence of such terminology in the opinion. See, e.g., Burnett, supra note 238 (drawing on the briefs as well as the opinion itself to expand her conception of the case).

306. Cabranes, supra note 13, at 458.

307. Id. at 458-63.

308. See Roper, supra note 119. 
Insular Affairs and its recently elevated chair, the lawyer William Jones of Virginia. ${ }^{309}$ In 1900, Jones had been a fierce critic of Republican imperialism, savaging Republicans for withholding U.S. citizenship from Puerto Ricans, "seven-tenths of [whom] belong to the Caucasian race," and for instituting in Puerto Rico "irresponsible carpetbag government." 310 By 1914, the gap between Democrats and Republicans on Puerto Rican policy had narrowed. As Republicans increasingly saw benefits to modest liberalization of U.S. policy in Puerto Rico, newly ascendant Democrats now in control of offices administering the island had come to see value in continuing a substantial federal role there. ${ }^{311}$ Leading members in each party thus now agreed that U.S. citizenship could be safely extended to Puerto Ricans, that such citizenship would signal permanent U.S. retention of Puerto Rico, and that the island was ready only for a modest expansion of self-government. ${ }^{312}$ In line with these views, Jones on February 24, 1914, introduced a bill under which Puerto Ricans would be collectively naturalized as U.S. citizens, gain an almost wholly elected island senate, and have an appointed governor with an absolute veto. $^{313}$

On March 11, new Bureau of Insular Affairs law officer Felix Frankfurter sent the Secretary of War a memo soon passed on to Congress that reviewed the implications of recent federal decisions and laws for potential U.S. policies for Puerto Rico. ${ }^{314}$ In the years since 1900, Justice Edward Douglas White's territorial nonincorporation doctrine had gained ground at the Court. The doctrine had, for instance, appeared to play increasingly central roles in a series of Supreme Court decisions that tracked Frankfurter's predecessor's 1900 analysis in denying that residents of territories such as Puerto Rico had jury rights under the Constitution. ${ }^{315}$ Nonetheless, the Court had yet to embrace the nonincorporation doctrine unequivocally. As a result, Frankfurter cited both Justice Henry Brown's and Justice White's opinion in Downes as authorities for what he perceived to be the controlling framework. ${ }^{316}$ Turning also to precedents involving Cuba, Hawai'i, the Panama Canal Zone, and the

309. Cabranes, supra note 13 , at 458-59.

310. 33 CONG. REC. APP. 232-35 (1900).

311. President Woodrow Wilson appointed a new Secretary of War and Governor of Puerto Rico, though he did not change the Chief of the Bureau of Insular Affairs. See, e.g., Gen. M'Intyre, 78, in Army 43 Years, N.Y. TIMES, Feb. 17, 1944, at 19; Policies of Our New War Minister, DET. FreE PRESS, Mar. 20, 1913, at 4; Porto Rico's Governor Sworn In, N.Y. TIMES, Nov. 7, 1913, at 8; War, WASH. POST, Oct. 31, 1915, at R3.

312. See text accompanying, discussion within, and external sources cited infra notes 325-32 (revealing widespread support for such a bill in 1916).

313. H.R. REP. NO. 63-461, at 2 (1914).

314. Civil Gov't for Porto Rico: Hearing on S. 4604 Before the S. Comm. on Pac. Islands and Porto Rico, 63d Cong. 21-24 (1914) [hereinafter 1914 SENATE HEARINGS], MD NARA 350/5B/ 488/3377-216.

315. See Rassmussen v. United States, 197 U.S. 516 (1905); Dorr v. United States, 195 U.S. 138 (1904); infra discussion within and external authorities in note 335.

316. See 1914 SENATE HEARINGS, supra note 314, at 21-24. 
Dominican Republic, Frankfurter argued that U.S. relations with dependent locales - including, presumably, whether to impose a tariff-were "matters solely for congressional competence." 317 That remained true, he elaborated, whatever the mix of constitutional rights, citizenship, and self-government that the United States put in place there. ${ }^{318}$

It is worth pausing here to note the enormous legal change underway. In 1900-1904, Supreme Court Justices had joined administrators and lawmakers in taking a tentative approach to the relationship between the Constitution and the U.S. imperial project. At the outset, lawmakers had explicitly denied Puerto Ricans only a single revenue-related constitutional protection and had taken no stand on the U.S. citizenship of Puerto Ricans or the eventual statehood of Puerto Rico. Many administrators, in turn, conceded rights to Puerto Ricans to avoid deciding constitutional questions concerning their status. And for their part, Supreme Court Justices together proved unwilling to adopt or reject the view that the United States could not hold colonies populated by noncitizen subjects. ${ }^{319}$ As the citation to Gonzales by the Senate Committee on Pacific Islands and Porto Rico and the citations to both Brown and White by Frankfurter reflected, nonjudicial U.S. officials recognized the resultant ambiguity and the freedom that it gave them in charting federal policies for U.S. imperial acquisitions. ${ }^{320}$ And although these political and administrative actors recognized that U.S. citizenship need not bring recipients many rights, they did not use the opportunity that the Court provided them to guarantee U.S. citizenship for all U.S. peoples and eventual statehood for all U.S. places.

317. Id. at 23; see id. at 21-24. That legislating for Puerto Rico would not tie Congress's hands concerning tariffs removed debate over the bill from the ongoing fight over protectionism. See generally, e.g., CÉSAR J. AYALA, AMERICAN SUGAR KINGDOM 48-73 passim (1999) (examining early twentieth-century complexities of setting tariffs on raw and refined sugar, the former of which was an input of the latter and both of which were produced domestically, in unincorporated territories, and overseas); Karen Schnietz, Democrats' 1916 Tariff Commission: Responding to Dumping Fears and Illustrating the Consumer Costs of Protectionism, 72 BUS. HIST. REV. 1 (1998) (explaining that tariffs were a key political issue, with Democrats supporting lower tariffs - including on sugar-while Republicans favored protection).

318. 1914 SENATE HEARINGS, supra note 314, at 21-24.

319. For recent work dispelling heroic visions of courts protecting individual rights in the face of the strong, persistent, uniform opposition from other powerful institutions, see, e.g., MICHAEL J. Klarman, From Jim Crow to Civil Rights (2004); Gerald N. Rosenberg, The Hollow Hope (1991); MARK TUSHNET, A COURT DIVIDED (2005); cf. Keck, supra note 7 (arguing that Klarman, Tushnet, and Rosenberg overstate judicial impotence); BARRY FRIEDMAN, THE WILL OF THE PEOPLE (2009) (arguing that courts have come to track public opinion closely while acknowledging exceptions that include the stickiness of precedents); KLARMAN, supra note 244 (describing how judges both advanced gay rights and provoked backlashes against them during the two decades preceding publication).

320. See also 1914 House HeARINGS, supra note 76, at 30-40. Freedom to set federal policy brought with it potential responsibility for those policies. Cf. WhITTINGTON, supra note 15, at 113, 124-26 (detailing benefits to regimes of using the Court to avoid deciding issues that threaten to unravel their coalitions); Howard Gillman, How Political Parties Can Use the Courts to Advance Their Agendas: Federal Courts in the United States, 1875-1891, 96 AM. POL. SCI. REV. 511, 513 (2002). 
Instead, War Department officials and congressional leaders from both parties came to pursue policies consistent with maintaining U.S. colonies and colonized peoples.

Unionistas recognized the unfolding transformation of the promise of U.S. citizenship for Puerto Ricans. As Unionistas testified to Congress, U.S. officials had already indicated that "American citizenship for Porto Ricans does not suggest the most remote intention on the part of the United States to ever grant statehood to [the Puerto Rican] people." ${ }^{321}$ Federal administrators and elected officials, they believed, instead envisioned U.S. citizenship for Puerto Ricans foreclosing independence for Puerto Rico and with it one potential path to island self-government. ${ }^{322}$ As a result, Unionistas worried, collective naturalization could make islanders "citizens of an inferior class" and Puerto Rico "perpetually a colony, a dependency." 323 These objections, the Washington Star reported, led congressional leaders to delay action on the bill in the 1913-1915 congressional term. ${ }^{324}$

Congress returned to consideration of new legislation for unincorporated U.S. territories in 1916. In line with Frankfurter's assurance that Congress had wide discretion in legislating for dependent locales and could treat each differently, lawmakers placed the Philippines and Puerto Rico on separate paths. This result was one that Degetau had unsuccessfully sought from all three branches of the federal government in 1900-1905. In January 1916, Chairman Jones introduced a new Puerto Rico bill similar to its immediate antecedent. $^{325}$ The basic contours of the bill still resembled those that Republican officials had previously proposed, and the bill retained the support of the President, the Governor of Puerto Rico, the Secretary of War, and Democratic sponsors in Congress. ${ }^{326}$ Unionistas now supported it as well, viewing it as the best immediately achievable result. ${ }^{327}$ Eight months later, the federal political branches enacted legislation for the Philippines. ${ }^{328}$ This law resembled the proposed bill for Puerto Rico in that it did not alleviate the colonial status of the people and places it touched. ${ }^{329}$ It differed from the Puerto Rico bill—which proposed to make Puerto Rico into a permanent U.S. territory

321. 1914 HOUSE HEARINGS, supra note 76, at 53-54.

322. Id. at $7-8$.

323. Id. at 53-54.

324. Porto Ricans Hope for U.S. Citizenship, WASH. STAR, Jan. 9, 1916, MD NARA 350/5B/492/3377A-4.

325. H.R. REP. NO. 64-77, at 1-2 (1916); 53 CONG. REC. 1340 (1916).

326. El Bill Jones, LA DEMOCRACIA, July 28, 1916, at 1; Interview with the Governor (Beckwith trans., 1916), MD NARA 350/5B/492/3377A-7 (Spanish-language source article printed in LA DEMOCRACIA, Feb. 5, 1916).

327. 53 CONG. REC. 7470-71 (1916) (remarks of Res. Com'r Luis Muñoz Rivera of P.R.); El Bill Jones, LA DeMOCRACiA, Jan. 27, 1916, at 4; El Bill Jones es superior a la ley Foraker, LA DEMOCRACIA, Feb. 11, 1916, at 2.

328. Jones Act (Philippines), Pub. L. No. 64-240, 39 Stat. 545 (1916).

329. See id.; Jones Act (Puerto Rico), Pub. L. No. 64-368, 39 Stat. 951 (1917). 
and Puerto Ricans into U.S. citizens - by announcing U.S. support for eventual Filipino independence and declining to recognize Filipinos as U.S. citizens. ${ }^{330}$ As U.S. entry into World War I loomed in early 1917, the Secretary of Warwho was also a lawyer - nudged Congress into action on Puerto Rico, writing, "The whole moral dominance of the... United States in the American Mediterranean is involved in our treatment of the people of Porto Rico." ${ }^{331}$ In March 1917, Jones's bill became the duly enacted Jones Act. ${ }^{332}$

Unequivocal recognition by the Supreme Court of the discretion of the political branches over Puerto Rican and Filipino status came later. Balzac v. Porto Rico (1922) presented the question whether the Jones Act had incorporated Puerto Rico and thereby extended jury rights to Puerto Ricans. ${ }^{333}$ By this point, eight of the nine justices who had heard Downes were no longer on the Court. ${ }^{334}$ Speaking for all his brethren, Chief Justice William Howard Taft began by unequivocally embracing the territorial nonincorporation doctrine. ${ }^{335} \mathrm{He}$ then acknowledged that the Court's prior explications of the nonincorporation doctrine had stated that statutory naturalization of a people

330. See Jones Act (Puerto Rico), Pub. L. No. 64-368, §5, 39 Stat. 951, 953 (1917); Jones Act (Philippines), Pub. L. No. 64-240, pmbl., § 2, 39 Stat. 545, 545-46 (1916); supra note 322 and accompanying text.

331. Letter from Newton Baker to John Shafroth (Feb. 16, 1917), MD NARA 350/5B/489/3377-327; see also 1 WORLD WAR I ENCYCLOPEDIA 273 (Spencer C. Tucker et al. eds., 2005).

332. Jones Act (Puerto Rico), Pub. L. No. 64-368, 39 Stat. 951 (1917); cf. MARY L. DUDZIAK, COLD WAR CIVIL RIGHTS (2000) (advocating greater attention to the role of foreign relations in legal change); Derrick A. Bell, Jr., Comment, Brown v. Board of Education and the Interest-Convergence Dilemma, 93 HARV. L. REV. 518 (1980) (suggesting that legal change favorable to those with limited power often results from temporary convergences of their interests with those of more powerful decision makers); RIVERA RAMOS, supra note 13, at 147-51 (collecting sources on motives behind the Jones Act (Puerto Rico)).

333. 258 U.S. 298 (1922).

334. See SPARROW, supra note 11, at 197.

335. See Balzac v. Porto Rico, 258 U.S. at 304-05. Scholars diverge as to when the nonincorporation doctrine became binding constitutional law. Compare Sarah H. Cleveland, Our International Constitution, 31 YALE J. INT'L L. 1, 47 (2006) (citing Dorr v. United States, 195 U.S. 138 (1904) as the key moment), with Andrew Kent, Boumediene, Munaf, and the Supreme Court's Misreading of the Insular Cases, 97 IowA L. REv. 101, 160 (2011) (citing Rasmussen v. United States, 197 U.S. 516 (1905) as the key moment), with Alan Tauber, The Empire Forgotten: The Application of the Bill of Rights to U.S. Territories, 57 CASE W. RES. L. REV. 147, 155, 163 (2006) (citing Balzac v. Porto Rico, 258 U.S. 298 (1922), as the key moment), and SPARROW, supra note 11, at 5 (similar). The case for Dorr is too subtle by half, for Justice Henry Brown joined the opinion of the Court in Dorr despite strongly opposing nonincorporation before and after. See Downes v. Bidwell, 182 U.S. 244 (1901); Rasmussen v. United States, 197 U.S. 516, 531 (1905) (Brown, J., concurring). While Rassmussen was a substantial step toward unequivocal embrace, doubts remained. See, e.g., SPARROW, supra note 11, at 189-90 (noting that Justice White sought to ensure his view of the case by telling the Court reporter, "now Downes vs. Bidwell is the opinion of the Court and I want you to make it so appear"); JAMES BRADLEY THAYER, LEGAL ESSAYS 171 (1908) (writing that, notwithstanding Rassmussen, no existing decision "has thoroughly dealt with the matter, or can be regarded as at all final"); supra text accompanying and external sources in notes 315-16. I join those for whom Balzac culminates a long process of nonincorporation becoming legal orthodoxy. See, e.g., SPARROW, supra note 11 , at 189 . 
generally also brought incorporation of their territory. ${ }^{336}$ Although the Court's prior articulations of this principle had suggested that it applied only prospectively, to statutory actions postdating the announcement of the territorial nonincorporation doctrine, Taft now intimated otherwise. Asserting that the subsequent "constant recurrence of the subject in the Houses of Congress[] fixed the attention of" legislators on the question, he announced that "incorporation is not to be assumed without express declaration, or an implication so strong as to exclude any other view."337 Finding no such declaration or implication in the Jones Act of 1917, Taft announced for the Court that Puerto Rico-like the Philippines - remained unincorporated. ${ }^{338}$ The Constitution did not require jury trials there. ${ }^{339}$

Three years later, the Court in Toyota $v$. United States addressed whether Filipinos were eligible to naturalize under federal statutes. ${ }^{340}$ The Justices did not follow the path they had pursued in Balzac, in which they expressly acknowledged and answered questions concerning the validity of the territorial nonincorporation doctrine. Instead, the Toyota Court appeared, at least for purposes of the case, to presume a preexisting negative to the question that Gonzales had in fact reserved: Were Puerto Ricans and by extension Filipinos U.S. citizens? Reasoning that a federal law that permitted naturalization of "[p]ersons not citizens who owe permanent allegiance to the United States" did not encompass most Filipinos of color, the Court did not question that Filipinos would otherwise be eligible noncitizens. ${ }^{341}$

More explicit Supreme Court recognition of the noncitizenship status of Filipinos followed decisions by elected officials and administrators to impose stringent immigration quotas on Filipinos in 1934, to strip Filipinos of their U.S. nationality upon Filipino independence in 1946, and to deport certain Filipinos as aliens thereafter. ${ }^{342}$ In response to one such deportation, the Court announced in Barber v. Gonzales (1954) that though Filipinos were not aliens before 1946, "neither could they become United States citizens." 343 Even so, an express holding on the citizenship status of Filipinos remained elusive.

The apparent distinction in citizenship status between Puerto Ricans and Filipinos proved consequential for Puerto Ricans as well. Because the political

336. See Balzac, 258 U.S. at 309.

337. Id. at 306.

338. See id. at $313-14$.

339. Id.

340. 268 U.S. 402 (1925)

341. Id. at 411 passim (quoting the Act of 1906, Pub. L. No. 338, §30, 34 Stat. 596, 606).

342. See Philippine Independence Act, Pub. L. No. 73-127, § 8(a)(1), 48 Stat. 456, 462 (1934); Rabang v. Boyd, 353 U.S. 427 (1957); Barber v. Gonzales, 347 U.S. 637, 639 n.1 (1954); Kendall Foss, New Filipino Immigration Quota Starts, WASH. POST, May 3, 1934, at 9; REPUBLIC OF THE

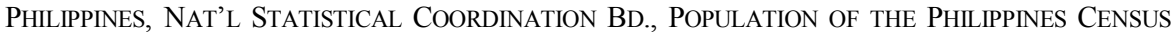
YEARS 1799 TO 2007, available at http://www.nscb.gov.ph/secstat/d_popn.asp (last visited June 22, 2014).

343. See 347 U.S. 637,639 n.1. 
branches made nearly all Puerto Ricans U.S. citizens in 1917, they continued and continue to enjoy the freedom to migrate within U.S. lands. Today, more U.S. citizens of Puerto Rican descent live outside the island than on it and Puerto Ricans on the mainland make up the second-largest group of Latinos there. $^{344}$

Reflecting on events a year after Toyota issued, Frederic Coudert described the Insular Cases as presenting the Supreme Court a choice between its "reverence for the Constitution" and allowing "the United States properly to govern a people so alien." 345 These two conflicting desires, he told Columbia Law Review readers, "were reconciled by [an] ingenious and original doctrine." The key strength of the doctrine: its "very vagueness ... was valuable." 346 Despite the ever-lengthening history of U.S. relations with Puerto Rico, Coudert's analysis remains relevant. More than a century after annexation, the Court has specified few constitutional rights that Puerto Ricans and other residents of unincorporated territories lack. ${ }^{347}$

Prior to mid-1905, Degetau had joined and at times influenced struggles over Constitution and empire that had changed the legal landscape and meanings of U.S. citizenship in uncertain ways. Working afterward and without Degetau in the shadow of these shifts - which included ambiguous Supreme Court doctrinal innovations - federal administrators and presidents together with elected Puerto Ricans and U.S. congressmen charted a rough course for Puerto Rico distinct from that set for the Philippines. In the years following, as the Supreme Court validated choices made by these nonjudicial actors, it added additional degrees of clarity to a legal landscape that nonetheless remained far from clear. ${ }^{348}$

\section{CONCLUSION}

In Washington, Degetau had sought through legally infused arguments to bring the cacophonous views of administrators, judges, and elected officials into harmony behind this refrain: U.S. citizenship and full constitutional rights

344. Sonia G. Collazo et al., U.S. Census Bureau, Profile of the Puerto Rican PopUlation IN THE UNITED STATES AND PUERTO RiCO: 2008, 1-2 (2010), available at http://www.census.gov/hhes/socdemo/education/data/acs/index.html (last visited June 22, 2014).

345. Coudert, supra note 112 , at 850,828 .

346. Id. at 850 .

347. See Burnett, supra note 11, at 834-53 (arguing that as of 1922, the only doctrinal difference between the individual rights of residents of incorporated and unincorporated territories was that the latter - like states - did not have to use juries in local — as opposed to federal — courts); SPARROW, supra note 11, at 142-211 (similar); Cleveland, supra note 335, at 46-48 (similar); Gary Lawson \& Robert D. Sloane, The Constitutionality of Decolonization by Associated Statehood: Puerto Rico's Legal Status Reconsidered, 50 B.C. L. REV. 1123, 1146 (2009) (extending the point forward in time). But cf. Downes v. Bidwell, 182 U.S. 244 (1901) (upholding a tariff on shipments between Puerto Rico and New York despite the constitutional requirement of tariff uniformity within the United States); infra text accompanying notes $348,363$.

348. See supra note 347. 
for Puerto Ricans, and eventual statehood for Puerto Rico. At once incisive and naïve, Degetau's vision captured key truths. U.S. officials held diverse views, shared commitments to law, and interacted with each other as they addressed Constitution and empire. But much more than Degetau grasped, these officials were also committed to facilitating what they perceived to be the exigencies of imperial governance. As a result, and contrary to Degetau's expectations, the U.S. law of empire emerged slowly and ambiguously as U.S. officials acted tentatively and creatively - not clearly and conventionally - in responding to legal disputes over the status and rights of new U.S. acquisitions.

The U.S. officials whom Degetau joined in Washington were not of a single or certain mind regarding the ramifications of empire. To varying degrees, he observed, U.S. officials mixed together uncertainty over the constitutional flexibility that empire required; lingering commitments to the legal legacy of Reconstruction; depictions of the incapacity of colonized peoples; concerns that U.S. empire was illegitimate, unconstitutional, undemocratic, or illiberal; and doubts as to whether law should and other federal officials would uphold differential treatment of Puerto Rico and the Philippines.

Despite their disagreements and uncertainty as to the substantive dictates of law, Degetau and his interlocutors shared commitments to legal methods and institutions. Degetau could perceive several: Jurists, activists, politicians, and officials framed debates over U.S. empire in constitutional terms. Claims involving legal arguments proved to be effective tools with which to elicit governmental responses concerning constitutional underpinnings of empire, albeit often not the responses Degetau and other claimants desired. Lawyers and men with legal training occupied high posts within the federal government, and nearly every claim Degetau launched ended up on the desk of one of them. Socialized into legal culture and having secured their posts in part based on their legal acumen, many of these officials deployed their legal expertise as they sought authority and autonomy, acknowledged the supremacy of courts, and maneuvered to influence and insulate themselves from judicial review. ${ }^{349}$ Justices, for their part, appeared committed to reconciling the Constitution and empire. They proceeded tentatively, eschewing holdings that would impede imperial governance or declare it entirely and unequivocally constitutional. ${ }^{350}$

349. On deploying legal expertise to secure authority and autonomy, see, for example, Daniel R. Ernst, Lawyers, Bureaucratic Autonomy, and Securities Regulation During the New Deal (Georgetown Public Law, Working Paper No. 1470934, 2009), available at $\mathrm{http} / / /$ ssrn.com/abstract=1470934. On judicial supremacy over constitutional meaning as the result of a slow process that remained far from complete at the turn of the last century, see MAGLIOCCA, supra note 77, at 4, 81-83, 123, 150; WHITTINGTON, supra note 15; Desai, supra note 18.

350. Cf. Reuel E. Schiller, The Era of Deference: Courts, Expertise, and the Emergence of New Deal Administrative Law, 106 MicH. L. REV. 399 (2007) (describing justices' perceptions that courts lacked the institutional skills to second-guess agencies productively). On judges as feeling at least somewhat bound by law, see, e.g., Duncan Kennedy, Toward an Historical Understanding of Legal Consciousness: The Case of Classical Legal Thought in America, 1850 
Amidst this complex landscape, Degetau saw opportunities to shape the laws and policies of the U.S. empire-state for himself and the judges, administrators, and elected officials before whom he appeared. ${ }^{351}$ Yet, Degetau was unable to win official embrace of his constitutional contentions. As Degetau realized early in his tenure, his failures before the political branches in 1900-1905 partly arose because lawmakers, who worried about retaining flexibility in imperial governance, acted in the shadow of courts. Concerned that embracing Puerto Ricans too fully would create precedents to which the Supreme Court might hold the political branches in governing ostensibly racially inferior Filipinos, lawmakers extended Puerto Ricans few rights, no U.S. citizenship or traditional territorial status, and little self-government in the Foraker Act (1900). Mostly, the Act left matters vague, depriving Degetau of potential test cases. It also framed a test case on a taxing issue that could be decided narrowly, raising the possibility of a loss for the government that would not be devastating. It simultaneously reduced the likelihood of such a loss by altering the official landscape so that a ruling for the government on the tax issue would also be a decision to decline to impede already-underway imperial governance. When Degetau threatened to bring a test case seeking a passport that designated him a U.S. citizen, lawmakers mooted such claims by conceding to U.S. insular residents the access to passports and consular protections that Degetau sought.

With Congress largely closed to him, Degetau turned to administrative authorities and then to courts. Both, he knew, played roles in imperial governance and in giving shape to the law of empire. Both found it profitable to decline to provide the clarifications that Degetau sought.

Nonetheless, Degetau persevered in revering law and adjudication. During four years in Washington, he had approached judges - and to a lesser degree administrators acting in adjudicatory capacities - as though they would rush in where other federal officials feared to tread. He envisioned these judges and adjudicating administrators answering properly presented claims, standing

1940, 3 Res. L. \& Soc. 3, 6, 23-24 (1980); Howard Gillman, The Constitution Besieged 16-18 (1993); Peter Karsten, Heart Versus Head (1997). On judges as committed to the norms of legal communities, see, for example, LAURENCE BAUM, JUDGES AND THEIR AUDIENCES (2006); Whittington, supra note 7.

351. See Frymer, supra note 7, at 782, 787-91 (arguing that courts play active roles in shaping and constructing state power, that the lawyers who appear before courts are institutionally situated to influence them, and that the power of courts derives in part from divisions within dominant political regimes); Joondeph, supra note 7, at 366-70; Keck, supra note 7, at 517, 532 (noting judicial autonomy where dominant regimes are divided on an issue); Reuel E. Schiller, Enlarging the Administrative Polity: Administrative Law and the Changing Definition of Pluralism, 1945-1970, 53 VAND. L. REV. 1389 (2000); supra discussion within, text accompanying, and sources cited infra notes 8, 96; supra notes 9-10, 94, 128, 131, 319-20, 349-50 and accompanying text. 
aloof from political controversies, and fully implementing legal principles. ${ }^{352}$ After his tenure as Resident Commissioner, he maintained his faith.

It is tempting to dismiss Degetau's judicial orientation as self-promotion or the delusion of one subject to the siren call of law. ${ }^{353}$ But Degetau's claims - especially those before administrators and judges-won his countrymen gains, including nonalienage, passports, a voice on the floor of the House of Representatives, free migration throughout U.S. lands, and access to federal civil-service and navy-yard jobs. ${ }^{354}$ When Degetau's successors turned to more political strategies, a dozen years of work secured for them only a modest liberalization of U.S. rule. ${ }^{355}$

Degetau achieved what he did in part by viewing administrators as potential agents of constitutional change. In some cases, administrators sought out this mantle, as when Charles Magoon and Felix Frankfurter, law officers within the War Department, proposed influential legal theories of empire to the U.S. political and judicial branches. In other cases, administrators had opportunities to create persuasive precedents, showcase avoidance strategies, or provide bases for test cases as they responded to properly presented controversies of constitutional moment.

One such controversy gave rise to Gonzales v. Williams (1904), which laid foundation for recognition of Puerto Ricans as U.S. citizens. In avoiding the question of Puerto Ricans' U.S. citizenship by ruling for Gonzalez solely on the basis of her non-alienage, the Court embraced and modeled evasion by concession. Over time, administrators', lawmakers', and judges' iterative uses of the approach delinked U.S. citizenship for Puerto Ricans from numerous rights and thereby reduced for them the distance between citizenship and nationality. Doing so lowered the stakes of naturalization. By signaling its reluctance to declare Puerto Ricans and Filipinos to be U.S. citizens, the Gonzales Court also transformed that question - for practical purposes-from a judicial to a political one.

This reinterpretation of Gonzales points the way to a new understanding of the 1901-1925 Insular Cases. Partly based on Justice White's opinion, existing accounts have identified Downes ${ }^{356}$ as the most important Insular

352. See supra note 127 and accompanying text; BAUM, supra note 350; Whittington, supra note 7 , at $608,613,621-23$.

353. Cf. ROSENBERG, supra note 319, at 341 ('“C]ourts act as 'fly-paper' for social reformers who succumb to the "lure of litigation."').

354. Cf. Silverstein, supra note 16, at 1087 (arguing that while recourse to courts is dangerous for those who have political pathways to achieving their policy preferences, it is sensible for those lacking such options). For other gains that Degetau won, see Erman, supra note 15, at 77-195.

355. See Jones Act (Puerto Rico), Pub. L. No. 64-368, 39 Stat. 951 (1917); Erman, supra note 15, at 197-277. But cf. supra notes 342-44 and accompanying text (relating how U.S. citizenship secured Puerto Ricans one constitutional right that came to prove consequential: freedom of movement throughout the United States).

356. Downes v. Bidwell, 182 U.S. 244 (1901). 
Case. ${ }^{357}$ Scholars have variously portrayed the case as denying recently acquired U.S. lands and peoples an array of constitutional rights, ${ }^{358}$ eventual statehood, ${ }^{359}$ or immunity from potential deannexation. ${ }^{360}$ But Downes had no majority opinion, ${ }^{361}$ and the Court unequivocally embraced the nonincorporation doctrine only after more than two decades. ${ }^{362}$ Today it remains unclear what constitutional rights residents of unincorporated territories lack. ${ }^{363}$ And it is hard to imagine the Court ever insisting that incorporated territories either become states ${ }^{364}$ or remain within the Union. ${ }^{365}$

Extant treatments also tend to downplay what is arguably the clearest consequence of the Insular Cases, that those born in unincorporated territories do not, as a practical matter, enjoy Fourteenth Amendment birthright citizenship. This result, to which the Court contributed by building on Gonzales rather than Downes, ${ }^{366}$ created a rule that proved consequential for Filipinos and Puerto Ricans. Under it, Filipinos lost their U.S. nationality by the millions following Filipino independence, and those born in Puerto Rico learned that their U.S. citizenship arose by operation of statute rather than as a constitutional guarantee.

More important than differences between Gonzales and Downes are their similarities. In 1898 but not in 1917, many U.S. commentators and officials

357. See, e.g., SPARROW, supra note 11, at 79-110; Vignarajah, supra note 78, at 789.

358. See, e.g., Burnett, supra note 11, at 800-01, 805-09, 820-21 (listing sources); Jasmine B. Gonzales Rose, The Exclusion of Non-English-Speaking Jurors: Remedying a Century of Denial of the Sixth Amendment in the Federal Courts of Puerto Rico, 46 HARV. C.R.-C.L. L. REV. 497, 511, 513-14 (2011); Kent, supra note 335, at 108-09; Saikrishna Prakash, Against Tribal Fungibility, 89 CoRNELL L. REV. 1069, 1091 (2004).

359. See, e.g., Burnett, supra note 11, at 800-01 (listing sources); SPARROW, supra note 11, at 250; Christina Duffy Burnett \& Burke Marshall, Between the Foreign and the Domestic: The Doctrine of Territorial Incorporation, Invented and Reinvented, in FOREIGN IN A DOMESTIC SENSE, supra note 11, at 1-2; Edward C. Carter, III, The Extra-Territorial Reach of the Privilege against SelfIncrimination or Does the Privilege "Follow the Flag?”, 25 S. ILL. U. L.J. 313, 320 (2001); Lawson \& Sloane, supra note 347 , at 1145.

360. See SPARROW, supra note 11, at 238-40, 247, 251; Burnett, supra note 11 passim.

361. See Downes, 182 U.S. 244.

362. See supra text accompanying and external sources in notes 315-16; supra note 335 and accompanying text.

363. See supra notes $347-48$ and accompanying text.

364. See U.S. CONST. art. IV, $\S 3$.

365. See Allan Erbsen, Constitutional Spaces, 95 MinN. L. REV. 1168, 1201 n.122 (2011) (citing Jones v. United States, 137 U.S. 202, $212(1890)$ as authority for deannexation being a political question); $c f$. Rivera v. Congress, 338 F. Supp. 2d 272, 279 (D.P.R. 2004) (citing political-question doctrine in finding no judicial authority to mandate independence for Puerto Rico while presuming Congress has such authority); Colon v. U.S. Dep't of State, 2 F. Supp. 2d 43, 46 (D.D.C. 1998) (similar); Burnett, supra note 11, at 864-70 (suggesting that controversy surrounded the question of deannexation in the immediate aftermath of U.S. annexation of Puerto Rico, Guam, and the Philippines by citing Justice Edward White's writings as authority both for the possibility and potential impossibility of deannexation while also noting that most commentators believed deannexation to be unproblematic).

366. Barber v. Gonzales, 347 U.S. 637, 639 n.1 (1954); Toyota v. United States, 268 U.S. 402, $411(1925)$. 
along with some leading Puerto Rican political men equated U.S. annexation with immediate extension of U.S. citizenship, eventual statehood, and full constitutional protections. ${ }^{367}$ Examining Downes and Gonzales together suggests that the Court may have driven that legal change in conjunction with lawmakers, administrators, and the President through doctrinal creativity, ambiguity, and tentativeness. ${ }^{368}$ In Downes, Justice White proposed the territorial nonincorporation doctrine under which affected territories received no promise of statehood and their residents received only fundamental constitutional rights. As contemporaries noted, the reach of the opinion was doubly ambiguous, for it neither enjoyed majority support nor provided detail on how to categorize constitutional rights. ${ }^{369}$

Gonzales, although a unanimous decision, also rested on judicial creativity and ambiguity. Its decision to recognize Puerto Ricans' nonalienage while reserving the question of their U.S. citizenship only made sense as a result of the Court's implicit contemplation of the novel status of the noncitizen U.S. national.

Operationalization of the Downes and Gonzales innovations first came from outside the courts. After War Department Law Officer Felix Frankfurter told lawmakers that they could extend or withhold U.S. citizenship on terms of their choosing, the political branches made Puerto Ricans and not Filipinos U.S. citizens. Only in the 1920 s did the Court recognize the result by proclaiming the nonincorporation doctrine, delinking U.S. citizenship from eventual statehood and full constitutional rights, and indicating (though never holding) that U.S.-national Filipinos lacked U.S. citizenship.

Perhaps it should not be surprising that the Court did not unequivocally embrace the Downes and Gonzales innovations for more than two decadesand not until after the political branches and the administrative department responsible for administering Puerto Rico had signaled their approval of both. U.S. acquisitions of Hawai'i, Guam, the Philippines, and Puerto Rico sparked roiling U.S. debates over the desirability, constitutionality, and significance of imperialism. ${ }^{370}$ U.S. officials from across the U.S. state, Degetau discovered, managed the competing commitments, uncertainty, and potential opposition

367. See Erman, supra note 15, at 7-8.

368. Rather than ask how judicial legal analysis differs from that by others in the state, see, e.g., Graber, supra note 17, at 35; Keck, supra note 7, at 532; Whittington, supra note 7, at 608; $c f$. Joondeph, supra note 7 (cataloging potential lines between law and politics), this observation opens the way to investigations of how courts, elected officials, and administrators develop law in conjunction, see, e.g., Silverstein, supra note 16, at 1089; cf. Keck, supra note 7, at 513 (criticizing consumers of Regime Theory for too often presuming that courts always act in subordination to political actors); Whittington, supra note 7, at 608-32 (stressing ways that courts are one institution among others in the U.S. state); Mark A. Graber, Dred Scott as a Centrist Decision, 83 N.C. L. REV. 1229, 1241 (2005) (similar); Joondeph, supra note 7, at 378-79 (similar); Vignarajah, supra note 78, at 835-44 (similar).

369. See, e.g., supra note 104

370. See BEISNER, supra note 36, at 221. 
[Vol. 102:1181

that resulted by proceeding tentatively along similar tracks. Although the details of this process are beyond the scope of this paper, observing the early Insular Cases and the dynamics in which they were enmeshed from Degetau's vantage does bring its broad contours into relief. The constitutional law of empire emerged iteratively as judges, administrators, and elected officials each influenced, deferred to, and reinforced the innovations of the others. Throughout, these actors deployed forms of creative ambiguity to manageand eventually settle - perceived conflicts between Constitution and empire. ${ }^{371}$

371. On legal change unmarked by holdings, see Whittington, supra note 7, at 621 . Among the many works advocating or undertaking such approaches like that suggested here, see Whittington, supra, at 621. Cf. supra note 10. 


\section{APPENDIX: LIST OF ABBREVIATIONS}

AG/DE/SPR/COS

CDO:

CIHCAM _/_

CIHCAM_/L

DC NARA 85/__ _ I

MD NARA, 350/_/_

WWP, NYPL _ _
Archivo General de Puerto Rico, Fondo del Departamento de Estado, Sección del Secretario de Puerto Rico, Serie del Correspondencia Oficina del Secretaria

El Centro de Documentación Obrera Santiago Iglesias Pantín, Microfilm Collection, Roll

Centro de Investigaciones Históricas, Colección Angel M. Mergal, caja, cartapacio, documento

Centro de Investigaciones Históricas, Colección Angel M. Mergal, caja, libro

District of Columbia National Archives and Records Administration, Record Group 85, Entry, Volume number out of total number of volumes, Page, No.

Maryland National Archives and Records Administration, Record Group 350, Series, Box, File

William Williams Papers, New York Public Library, Box, Folder 
